\title{
TEACHING METHODOLOGY OF THE DIAGNOSING PROCESS ON THE EXAMPLE OF THE FIRE ALARM SYSTEM
}

\author{
METODYKA NAUCZANIA PROCESU \\ DIAGNOZOWANIA NA PRZYKLADZIE SYSTEMU \\ SYGNALIZACJI POŻARU
}

\author{
Jacek Paś, Tadeusz Dąbrowski, Michał Wiśnios
}

Military University of Technology, Wojskowa Akademia Techniczna

\begin{abstract}
The article presents a method of teaching the process of diagnosing the technical and functional condition of the fire alarm system (SSP). The fire alarm system's laboratory model is a representation of a real fire alarm system. The lecturer has the opportunity to inflict several different independent damage. The aim of the laboratory exercise is to familiarize students with the methodology and structure of the fire alarm system diagnosing process.
\end{abstract}

Keywords: detector, fire alarm system, diagnosis

Streszczenie: $W$ artykule przedstawiono metodę nauczania procesu diagnozowania stanu technicznego $i$ funkcjonalnego systemu sygnalizacji pożaru (SSP). Laboratoryjny model SSP jest odwzorowaniem rzeczywistego uktadu sygnalizacji pożaru. Prowadzacy zajęcia ma możliwość zadawania kilkunastu różnych niezależnych uszkodzeń. Celem ćwiczenia laboratoryjnego jest zapoznanie studentów z metodyka i struktura procesu diagnozowania SSP.

Stowa kluczowe: czujka, system sygnalizacji pożaru, diagnozowanie 
Teaching methodology of the diagnosing process on the example of the fire... Metodyka nauczania procesu diagnozowania na przykładzie systemu sygnalizacji...

\section{General characteristics of fire alarm systems}

In the situation of increasing requirements of buildings' users regarding their safety, functionality and operating costs, the civil structures are equipped with technical safety systems, including fire alarm systems $[2,4,9,10]$. The fire safety is a complex issue taking into account many factors, both the construction and installation (technical) ones. The fire alarm system is a basic safety system protecting the human life and health. The basic element, which determines the fire detection, includes detectors (sensors) responding to the changes in physical quantities accompanying fire. The uncontrolled fire may contribute to significant material damage, as well as it may be a direct threat to the health and life. In a certain class of large facilities (e.g. commercial buildings, theatres, cinemas, hospitals, railway stations), the use of fire alarm systems is necessary and at the same time mandatory (Fig. 1). In these buildings, there is a necessity not only to detect fire but also to find its source $[9,10,11]$. This requirement can be met through appropriate addressing of fire detectors.

Due to the fire alarm system type, the following kinds of addressing are distinguished:

- group addressing - involves indication of a surveillance line, to which the detector transmits a fire alarm signal. It allows to identify the affected area zone, in which the detector reacted to the fire source. The surveillance line number also includes the number of the zone, which can include, e.g. corridor, floor or e.g. a group of monitored premises;

- individual addressing - applies to individual detectors, groups of detectors and control elements installed in the surveillance line connected to the control panel. Each of these elements has an assigned individual address. It allows for identification of the hazardous area by the control panel as well as sending and receiving signals from the selected devices (identification is a function of the adopted surveillance area) $[6,7,9,10]$. In the way of addressing, it is possible to group the addressable network elements in special logical groups consisting of several surveillance zones.

Depending on a method for exchanging information between the devices connected to the transmission bus and the control panel, it is possible to distinguish:

- monologue systems, in which the detectors report to the control panel only when fire is detected. It is not possible to connect the actuators in these lines. The connection of actuators usually takes place through inputs in the control panel or with the use of special modules installed in the line;

- dialogue systems, in which the address element (e.g. detector) provides information on its state (fit - unfit), e.g.: in case of the polling procedure by the control panel. There is a mutual exchange of information between the fire alarm system's elements. 
The communication between the fire alarm system's elements can be carried out in the following way:

- current - sensor detects a fire hazard on the basis of the sudden increase in power consumption;

- pulse - address number of the detector is identified by the detector's current pulse. The pulse amplitude informs on the detector status. The delay in relation to the moment of the detector's activation constitutes information on an instantaneous value of fire parameters (analogue systems);

- digital - transmission involves the sequential transmission of encoded according to the specified protocol - digital data packages (Fig. 2) $[12,13,15]$. It is possible to identify the detector or any other element of the system by determining the type and current value of hazard parameters detected by a given type of the detector $[4,7,12,13]$.

The diagram of the fire alarm system with an indicated section, which is used in the teaching process of diagnosing, is presented in Fig. 1. One surveillance line with a short circuit isolator and a manual call point is connected to the control panel.

The existence of a large set of available states in the fire protection systems and a necessity of indicating the occurred fire risk in the protected facility with an accuracy of a single room forced the use of addressable detectors reacting to the fire emergence. The important feature of the fire alarm equipment and other alarm systems is a way of communication between the detectors and the control panel.

In the monologue systems, information is sent in one direction, and it means that the detectors report to the panel as the alarm is detected. There is a possibility of the collision occurrence in case of simultaneous triggering of two alarms, therefore, in order to eliminate this phenomenon, a random choice of the moment related to the activated detector triggering is applied. At the dialogue communication, there is bi-directional communication between the detector and the panel. The fire alarm system panel initiates "contact" with individual detectors, and then, the latter ones transmit the information which includes the detector number and data on the state of the environment around them. It allows to emit the conflict situations, false alarms, as well as to control the addressable devices installed on the surveillance lines.

In the fire alarm systems, it is possible to distinguish the following ways of addressing the detectors:

- addressing the detectors on the basis of measuring the degree of dividing the voltage dividers - monologue;

- addressing on the basis of the digital transmission - monologue;

- addressing in the pulse system - dialogue;

- addressing in the pulse system with time-division - monologue;

- addressing in the digital system - dialogue. 
Teaching methodology of the diagnosing process on the example of the fire... Metodyka nauczania procesu diagnozowania na przykładzie systemu sygnalizacji...

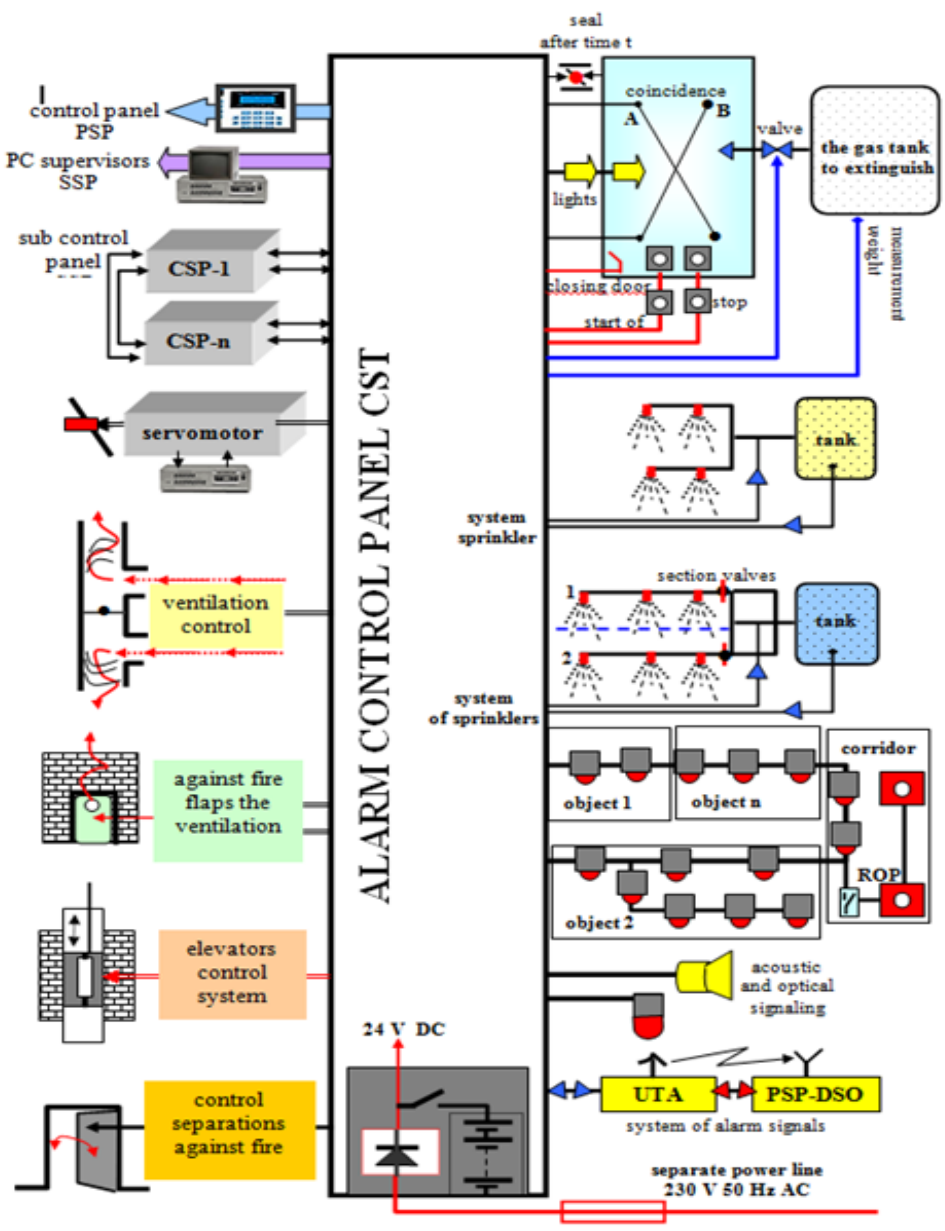

Fig. 1. Integrated fire alarm system used in the intelligent building $(X-$ detectors, surveillance lines in the teaching process of diagnosing)

The constant changes in the parameters of the detectors and control panel result from, among others, the ageing and wearing processes. These changes pose great difficulties in calculating the reliability of fire systems due to a stochastic and undefined nature of natural changes in the elements' parameters. The manufacturing dispersion determines the so-called initial reliability, sometimes referred to in the literature as schematic reliability. The occurrence of the damage associated with ageing processes results in the occurrence of the ageing fault, which according to the Polish Standard PN-90 /N-04002 (Technical diagnostics General terminology) is defined as follows: "ageing fault - unfitness resulting from the damage, the probability of which increases over time as a result of internal processes in the facility" in this case, that is the firefighting alarm system. 
The output parameters of each firefighting alarm system are specified by:

- parameters of the elements, which the system is built of;

- the internal structure of the alarm system connections (control panel - detectors - power supply - signalling devices, etc.).

Between $Đ$ output parameters of the firefighting alarm system and $x_{i}(i=1,2, \ldots, N)$ parameters of components, there is the functional relationship $\mathrm{Ð}=\mathrm{f}\left(\mathrm{x}_{1} ; \mathrm{x}_{2} ; \ldots, \mathrm{x}_{\mathrm{N}}\right)$ which adopts the following form for the relative increase

$$
\delta Đ=\mathrm{f}_{1}\left(\delta \mathrm{x}_{1} ; \delta \mathrm{x}_{2} ; \ldots, \delta \mathrm{x}_{\mathrm{N}}\right)
$$

The relationship (1) for small $\delta \mathrm{x}_{\mathrm{i}}(\mathrm{i}=1, \mathrm{~N})$ can be presented in a different form

$$
\delta Đ=\xi \mathrm{x}_{1}+\xi \mathrm{x}_{2}+\ldots+\xi \mathrm{x}_{\mathrm{N}}
$$

where

$$
\delta Đ=\frac{\bigoplus_{-} \bigoplus_{\mathrm{n}}}{\bigoplus_{\mathrm{n}}} ; \quad \delta x_{i}=\frac{\mathrm{x}_{\mathrm{i}}-\mathrm{x}_{\mathrm{in}}}{\mathrm{x}_{\mathrm{in}}} ; \quad \xi_{i}=\frac{\delta \mathrm{Ð}}{\delta \mathrm{x}_{\mathrm{i}}}
$$

markings: $\mathrm{n}$ - ratings of appropriate parameters of the fire fighting alarm system; $\xi$-influence coefficients which determine the increase $\delta Ð$ of the output parameter, resulted from the increase $\delta x_{i}$ of the parameter and - the element included in the fire fighting alarm system.

The influence coefficients $\xi_{\mathrm{i}}$ depend on the element location in the entire alarm system structure (e.g. one of the resistors polarising the transistor base in the signal amplifier circuit is located in the fire detector, and the resistor parametrising the surveillance line is in the line connected to the control panel. Therefore, the coefficients $\xi_{\mathrm{i}}$ are also called location coefficients.

In order to provide the operation of fire detectors and electronic addressing systems placed in their slots, an adequate level of the supply voltage is required. Table 1 shows the supply voltage levels of most commonly used detectors installed in fire fighting alarm systems - fig. 2.

Tab. 1. Permissible voltage levels supplying the detectors installed in the fire fighting alarm systems.

\begin{tabular}{|l|c|c|c|c|}
\hline Detector type & DF1101-Ex & DLO1191 $^{2}$ & G-3840 & $R O P-38 A^{4}$ \\
\hline Operating voltage $[\mathrm{V}]$ & $16 \div 28$ & $16.5 \div 24$ & $19.5 \div 24$ & $17 \div 24$ \\
\hline Quiescent current $[\mu \mathrm{A}]$ & 500 & 150 & 80 & 80 \\
\hline
\end{tabular}

Markings:

DF1101-Ex ${ }^{1}$ - addressable flame detector of SIEMENS company, DLO1191 ${ }^{2}$ addressable linear smoke detector of SIEMENS company, G-3840 ${ }^{3}$ - addressable socket of ALFA 3800 system / Polon - Alfa production/; ROP - $38 \mathrm{~A}^{4}$ - manual call point (addressable of ALFA 3800 system). 
Teaching methodology of the diagnosing process on the example of the fire... Metodyka nauczania procesu diagnozowania na przykładzie systemu sygnalizacji...
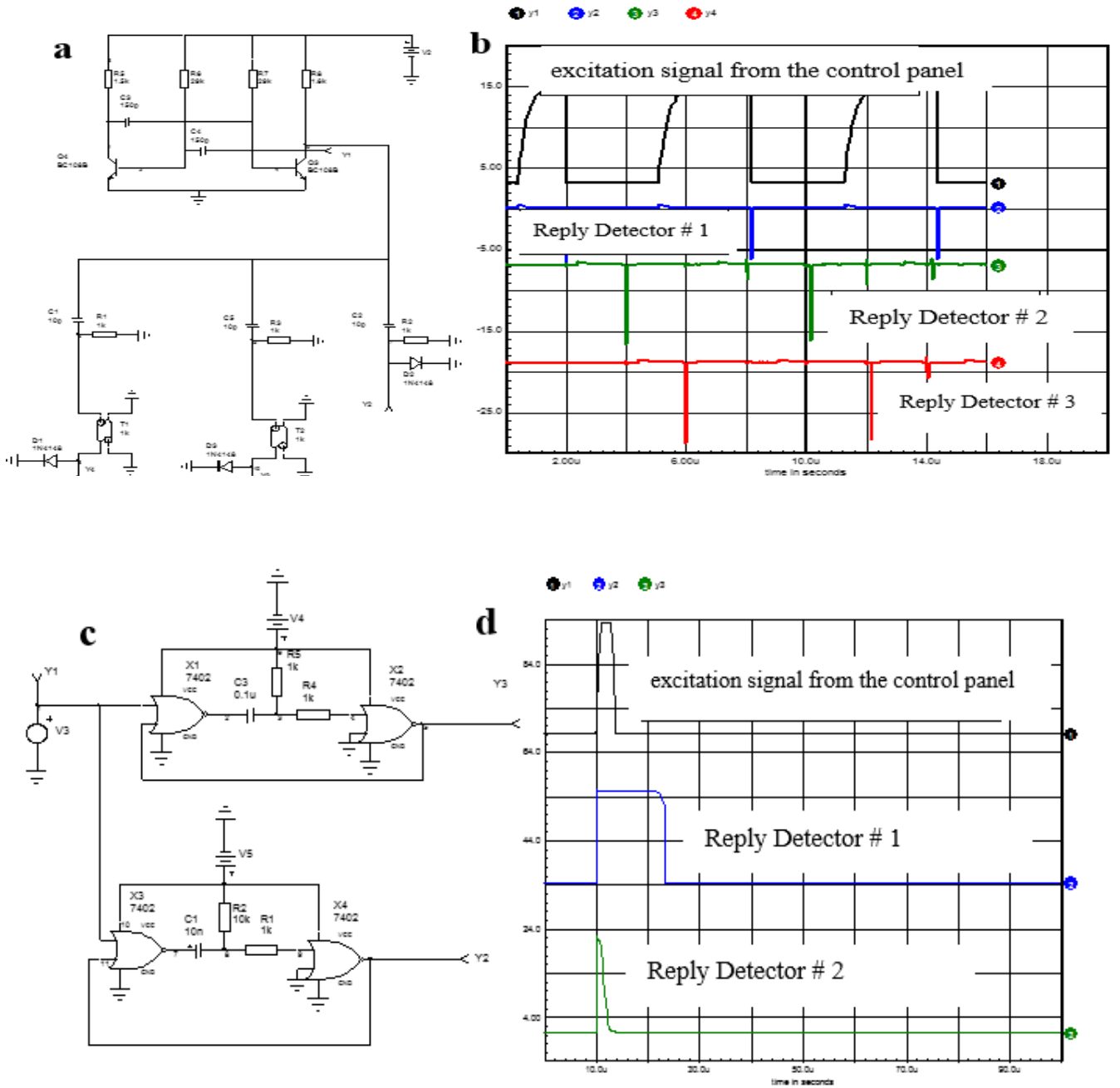

Fig. 2. Example methods for addressing the detectors in the safety system $(2 a, 2 c)$ and their corresponding time courses generated in the detectors $(2 b, 2 d)$.

The acceptable ranges of changes in the voltage supplying the detectors and addressing systems are within the limits $(16 \div 28) \mathrm{V}$ (the worst case), at the permissible operating temperature of $(-25 \div+60){ }^{0} \mathrm{C}$. The change in the supply voltage and temperature results in a change in the parameters of the addressing signals sent from the detector to the control panel. Tables 2, 3 and 4 show the effect of the above-mentioned changes on the response generated by the detectors located in the alarm system. 
Tab. 2. Addressing of the detectors on the basis of measuring the degree of dividing the voltage dividers - impact of $U_{\text {zas }}$ changes on the distribution value $U$ (Fig. $3 a$ ).

\begin{tabular}{|c|c|c|c|}
\hline $\begin{array}{c}\text { Supply } \\
\text { voltage U[V] }\end{array}$ & $\begin{array}{c}\text { Voltage divider } \\
\text { U[V] No. 1 }\end{array}$ & $\begin{array}{c}\text { Voltage divider } \\
\text { U[V] No. 2 }\end{array}$ & $\begin{array}{c}\text { Voltage divider } \\
\text { U[V] No. 3 }\end{array}$ \\
\hline 16 & 8 & 10.7 & 12 \\
U $_{\text {zn }}=24$ & 12 & 16 & 18 \\
28 & 14 & 18.7 & 21 \\
\hline
\end{tabular}

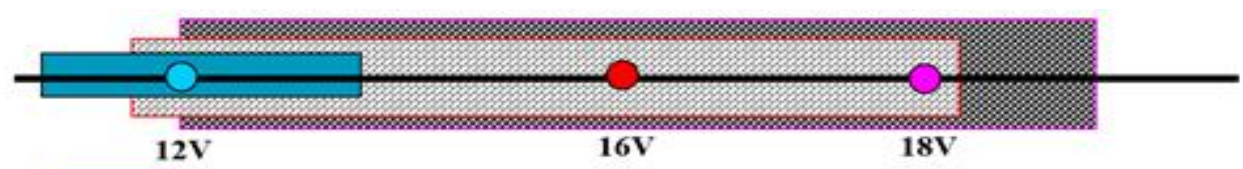

Range of $U_{w y j}$ changes of Dz1 divider under the influence of changes $U_{z a s}$ Range of $U_{w y j}$ changes of Dz2 divider under the influence of changes $U_{z a s}$ Range of $U_{\mathrm{wyj}}$ changes of Dz3 divider under the influence of changes $U_{\mathrm{zas}}$

Tab. 3. Addressing of the detectors in the pulse system with time-division-impact of $U_{z a s}$ changes and temperature on the value of duration $t_{i}$ of output pulses of detectors 2, 3 (diagram of connections Fig. 3.b).

\begin{tabular}{|c|c|c|c|}
\hline \multirow{2}{*}{$\begin{array}{l}\text { Change of } \\
\text { supply } \\
\text { voltage } \\
\text { U[V] }\end{array}$} & \multirow{2}{*}{$\begin{array}{c}\text { Change in } \\
\text { operating } \\
\text { temperature of } \\
\text { detectors }\left[{ }^{0} \mathrm{C}\right]\end{array}$} & \multicolumn{2}{|c|}{$\begin{array}{l}\text { Change in duration } t_{i}[\mu \mathrm{s}] \text { of pulses of the } \\
\text { response generated by detectors } 2,3\end{array}$} \\
\hline & & Detector No. 2 & Detector No. 3 \\
\hline \multirow{3}{*}{16} & -25 & 0.989108 & 1.98911 \\
\hline & +27 & 0.981997 & 1.98198 \\
\hline & +60 & 0.997871 & 1.97787 \\
\hline \multirow{3}{*}{$\mathrm{U}_{\mathrm{zn}}=24$} & -25 & 1.03695 & 2.03839 \\
\hline & +27 & 1.01843 & 2.01876 \\
\hline & +60 & 0.999206 & 1.99849 \\
\hline \multirow{3}{*}{28} & -25 & 0.989108 & 2.01411 \\
\hline & +27 & 1.00698 & 1.95698 \\
\hline & +60 & 0.977871 & 1.95287 \\
\hline
\end{tabular}

Detector \# 2

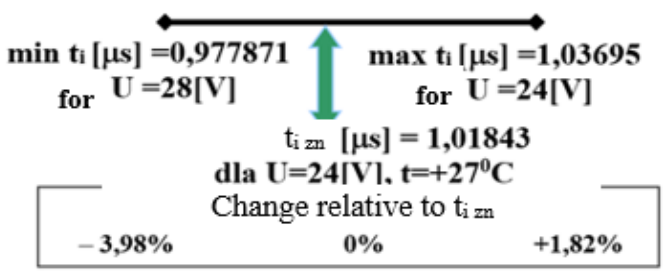

Detector \# 3

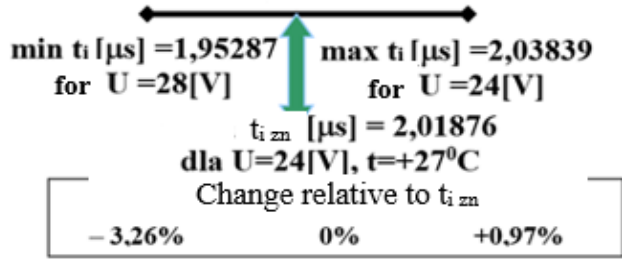


Teaching methodology of the diagnosing process on the example of the fire...

Metodyka nauczania procesu diagnozowania na przykładzie systemu sygnalizacji...

Table 4. Addressing of the detectors in the pulse system-impact of changes in the supply voltage and temperature on the value of duration $t_{i}$ of output pulses of detectors Nos. 1, 2 (diagram of connections Fig. 3.c).

\begin{tabular}{|c|c|c|c|}
\hline \multirow{2}{*}{$\begin{array}{c}\text { Change of } \\
\text { supply } \\
\text { voltage } \\
\text { U[V] }\end{array}$} & \multirow{2}{*}{$\begin{array}{c}\text { Change in } \\
\text { operating } \\
\text { temperature of } \\
\text { detectors }\left[{ }^{0} \mathrm{C}\right]\end{array}$} & \multicolumn{2}{|c|}{$\begin{array}{l}\text { Change in duration } t_{i}[\mu s] \text { of pulses of the } \\
\text { response generated by detectors } 1,2\end{array}$} \\
\hline & & Detector No. 1 & Detector No. 2 \\
\hline \multirow{3}{*}{16} & -25 & 14.0806 & 2.57144 \\
\hline & +27 & 13.4965 & 2.92067 \\
\hline & +60 & 13.8889 & 3.22735 \\
\hline \multirow{3}{*}{$\mathrm{U}_{\mathrm{znam}}=24$} & -25 & 14.2488 & 0.90855 \\
\hline & +27 & 13.8859 & 1.16986 \\
\hline & +60 & 13.2540 & 1.53392 \\
\hline \multirow{3}{*}{28} & -25 & 14.1160 & 0.509341 \\
\hline & +27 & 13.6008 & 0.791544 \\
\hline & +60 & 13.5369 & 0.959071 \\
\hline
\end{tabular}

Addressing of detectors in the safety systems is a very important technical problem because it is important to provide a suitable solution for changing operating conditions of the safety system - Fig. 3. In order to make the addressing correct, the specific safety margins of the voltage ranges of individual detectors must exist. Addressing of detectors in the pulse system with short duration carries a defect of large changes in the pulse duration (Table $4-$ detector No. 2). In this case, the application of the transmission of pulses with longer duration (Table 4 - detector No. 1) increases the stability of addressing of the detector.

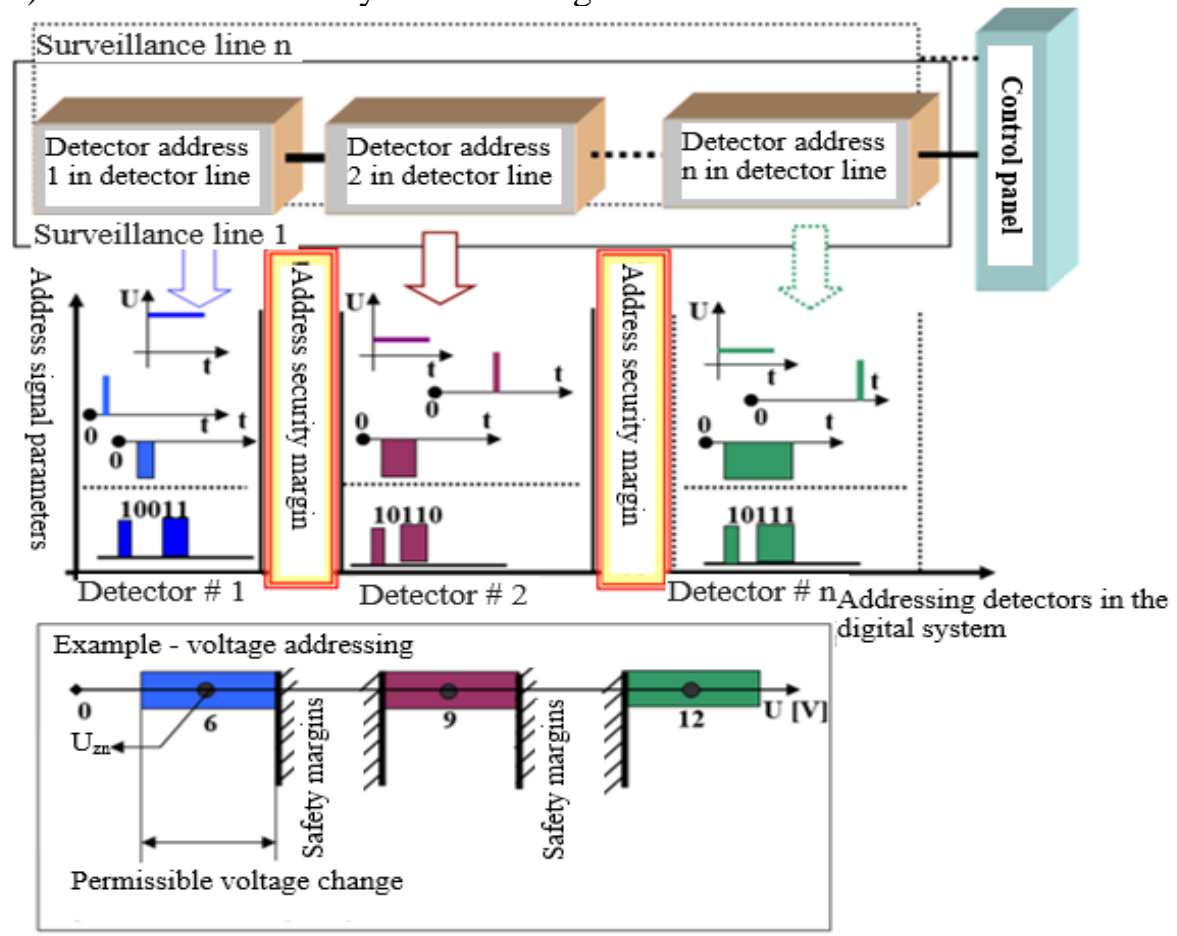

Fig. 3. Selected methods for addressing the detectors in the fire fighting alarm system 


\section{Laboratory model of the fire alarm system with surveillance lines}

At the Faculty of Electronics of Military University of Technology, the studies with the specialisation of "Engineering of Safety Systems" are conducted. During the classes with students within the subject of "Operation of safety systems", the laboratory exercises, which include the issues on diagnosing, are conducted in the seventh semester. The laboratory station presents a simple physical model of the fire alarm system consisting of the control panel with one surveillance line of the state of protected rooms [7]. In the surveillance line, there are three detectors operating in the pulse system with time-division. The general diagram of the fire alarm system was presented in Figure 4, 5.

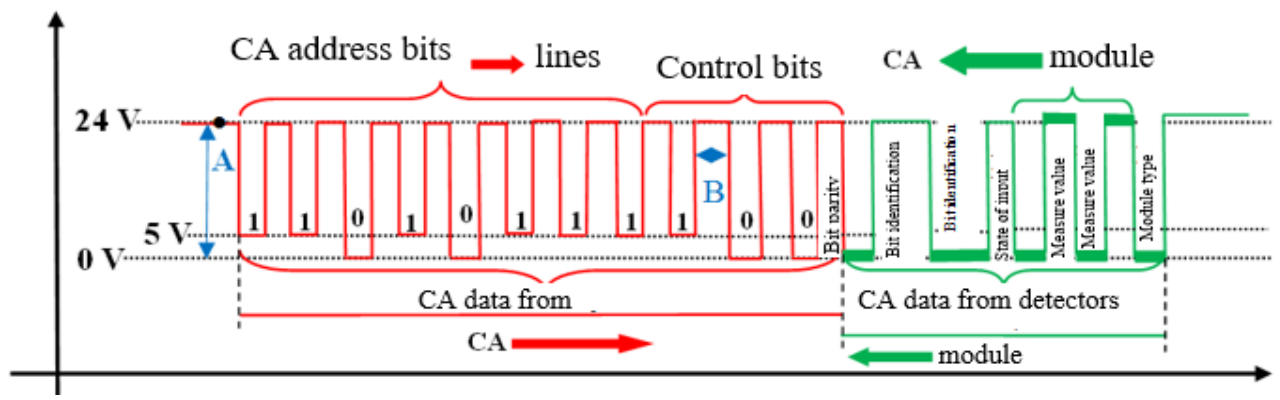

Fig. 4. Dialogue system in the fire alarm system-exchange of information of the control panel - element, device, detector on the surveillance line (markings: $A$-measurement of the pulse voltage values, $B$-measurement of the pulse duration-gates implemented in the laboratory exercise)

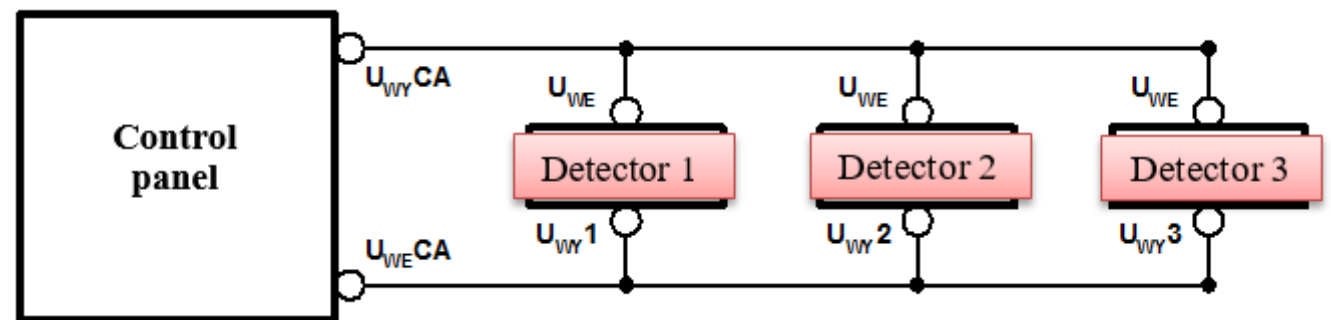

Fig. 5. Simplified diagram of the fire alarm system's diagnosed section

After sending a pulse by the control panel, the detector generates the pulse with a time delay $T_{i}$ depending on the detector number. $T_{i}=T_{1}$ or $T_{2}$, or $T_{3}$. After $T_{1}$ time, the detector No. 1 sends a pulse with the value depending on the detector status to the surveillance line. In subsequent intervals $T_{2}$ and $T_{3}$ the pulses are sent by the detectors No. 2 and 3. The input circuit of the panel controlling the amplitude values of pulses with the use of ladder comparators in the determined intervals identify the state of individual detectors. 
Teaching methodology of the diagnosing process on the example of the fire... Metodyka nauczania procesu diagnozowania na przykładzie systemu sygnalizacji...

In the further part of this paper, the time intervals are called "measuring gates". The location of pulses and measuring gates is shown in Figure 6.

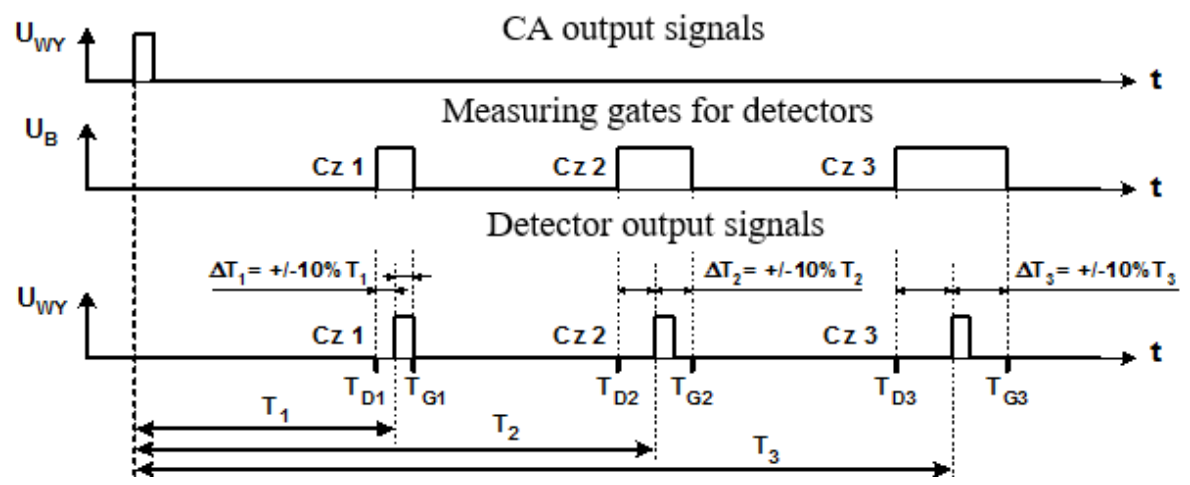

Fig. 6. Output pulses of the control panel and detectors

Markings in Fig. 6:

- $\mathrm{T}_{1}, \mathrm{~T}_{2}, \mathrm{~T}_{3}$ - time of shifting the output pulse leading edge of the detectors;

$-\Delta \mathrm{T} \quad-$ permissible range of the detector's output pulse shift;

$-\mathrm{T}_{\mathrm{D}} \quad-$ lower limit of the detector's output pulse shift;

- $\mathrm{T}_{\mathrm{G}} \quad-$ upper limit of the detector's output pulse shift.

The control panel distinguishes three values of output pulses from the detectors, which reflect: the state of damage, surveillance and alarm of the fire alarm system. The measurement of the amplitude of the output pulse of a given detector takes place only when the pulse leading edge occurs during the measuring gate. Otherwise, the pulse amplitude measurement system determines that the amplitude is equal to zero and the control panel generates a signal of "Damage".

A set of the laboratory station structurally includes a control and measuring panel and a digital oscilloscope.

This station allows to:

- measure T time of shifting the detectors' output pulses;

- measure the amplitude of voltage of the detectors' output pulses;

- measure lower $T_{D}$ and upper $T_{G}$ limits of shifting the output pulse of a given detector;

- measure limit values of the voltage amplitude of the detectors' output pulses, at which a change in the operating condition of the fire alarm system occurs;

- inflict damage to the fire alarm system.

The control and measuring panel includes:

- models of detectors and the control panel;

- breakers and switches controlling the station operation and potentiometers;

- measuring sockets and signalling diodes. 
The measuring sockets allow to observe the control panel and detectors' signals on the oscilloscope screen. The breakers marked with "Damage" $\left(\mathrm{U}_{1} \div \mathrm{U}_{14}\right)$ are used for inflicting damage. The diodes are used for signalling the operation status of the fire alarm system (as described on the front panel of the station - Fig. 5). In order to supply the station with the voltage of $230 \mathrm{~V}$, the breaker marked with "Network" is illuminated.

The shifting system of the detectors' output pulses is used for measuring lower $T_{D}$ and upper $\mathrm{T}_{\mathrm{G}}$ limits of shifting the output pulse of a given detector. The system consists of the switch $S_{I}$ marked with $T_{Z N}$ and Reg. $T$ and the potentiometer marked with Checking $T$. When the switch $\mathrm{S}_{1}$ is in the position of $\mathrm{T}_{\mathrm{ZN}}$, the detectors' output pulses are shifted in relation to the control panel's output pulse with ratings $T_{1}, T_{2}$ and $\mathrm{T}_{3}$ (see Fig. 7). After turning the switch $\mathrm{S}_{1}$ in the position of Reg. T, with the use of the potentiometer marked with Checking $T$, it is possible to change the position of the detectors' output pulses in the range of $\mathrm{T} \frac{+\mathbf{6 0 0}}{-\mathbf{5 0 0}} \mu \mathrm{s}$.

The measuring gates, in the form of pulses, cannot be observed on the oscilloscope screen.

The measuring system of limit values of the voltage amplitude of the detectors' output pulses is used for determining the amplitude values, at which a change in the operating condition of the fire alarm system occurs. The system consists of the switch $\mathrm{S}_{2}$ marked with $U_{Z N}$ and Reg. $U$ and the potentiometer marked with Checking $U$. When the switch $\mathrm{S}_{2}$ is in the position of $U_{Z N}$, the detectors' output pulses are provided to the control panel input. After turning the switch $\mathrm{S}_{2}$ in the position of Reg. $U$, the DC voltage is provided to the control panel input. By changing the voltage value, it is possible to determine limit values of the voltage amplitude of the detectors' output pulses, at which a change in the operating condition of the fire alarm system occurs, which is signalled by lighting the corresponding diode.

The characteristics of signals related to the control panel's and detectors' models:

1) The rated shifts of the detectors' output signals: $\mathrm{T}_{1}=1 \mathrm{~ms}, \mathrm{~T}_{2}=2 \mathrm{~ms}, \mathrm{~T}_{3}=3 \mathrm{~ms}$;

2) The ranges of permissible shifts of the detectors' output pulses: $\Delta \mathrm{T}_{1}=+/-100 \mu \mathrm{s}$, $\Delta \mathrm{T}_{2}=+/-200 \mu \mathrm{s}, \Delta \mathrm{T}_{3}=+/-300 \mu \mathrm{s}-$ figure 8

3) The amplitude of the detectors' output signals:

- $\mathrm{U}_{\mathrm{WY}}=0 \div 3 \mathrm{~V}-$ state of unfitness of the open-circuit type (i.e. between the control panel and the detector or inside the detector), or the reduced circuit resistance (probability of the damage occurrence is very small) - the control panel generates a signal of "Damage";

- $\mathrm{U}_{\mathrm{WY}}=3 \mathrm{~V} \div 6 \mathrm{~V}$ - state of ability - the control panel generates a signal of "Surveillance";

- $\mathrm{U}_{\mathrm{WY}}>6 \mathrm{~V}$ - state of ability - the control panel generates an alarm signal of "Fire".

At the post, it is possible to model the following damage:

- no signal at the input of the detector (detectors);

- no signal at the output of the detector (detectors);

- signal amplitude at the output of the detector (detectors) higher than the rated one; 
Teaching methodology of the diagnosing process on the example of the fire...

Metodyka nauczania procesu diagnozowania na przykładzie systemu sygnalizacji...

- signal shift at the output of the detector (detectors) different from the rated one;

- change in the position of lower $\mathrm{T}_{\mathrm{D}}$ and upper $\mathrm{T}_{\mathrm{G}}$ limits of shifting the output pulse of a given detector (shifting of the "measuring gate" - different from the rated one);

- measuring system of the voltage amplitude of the detectors' output pulses damaged in the control panel (rating means a range of values corresponding to the state of usability of the fire alarm system).

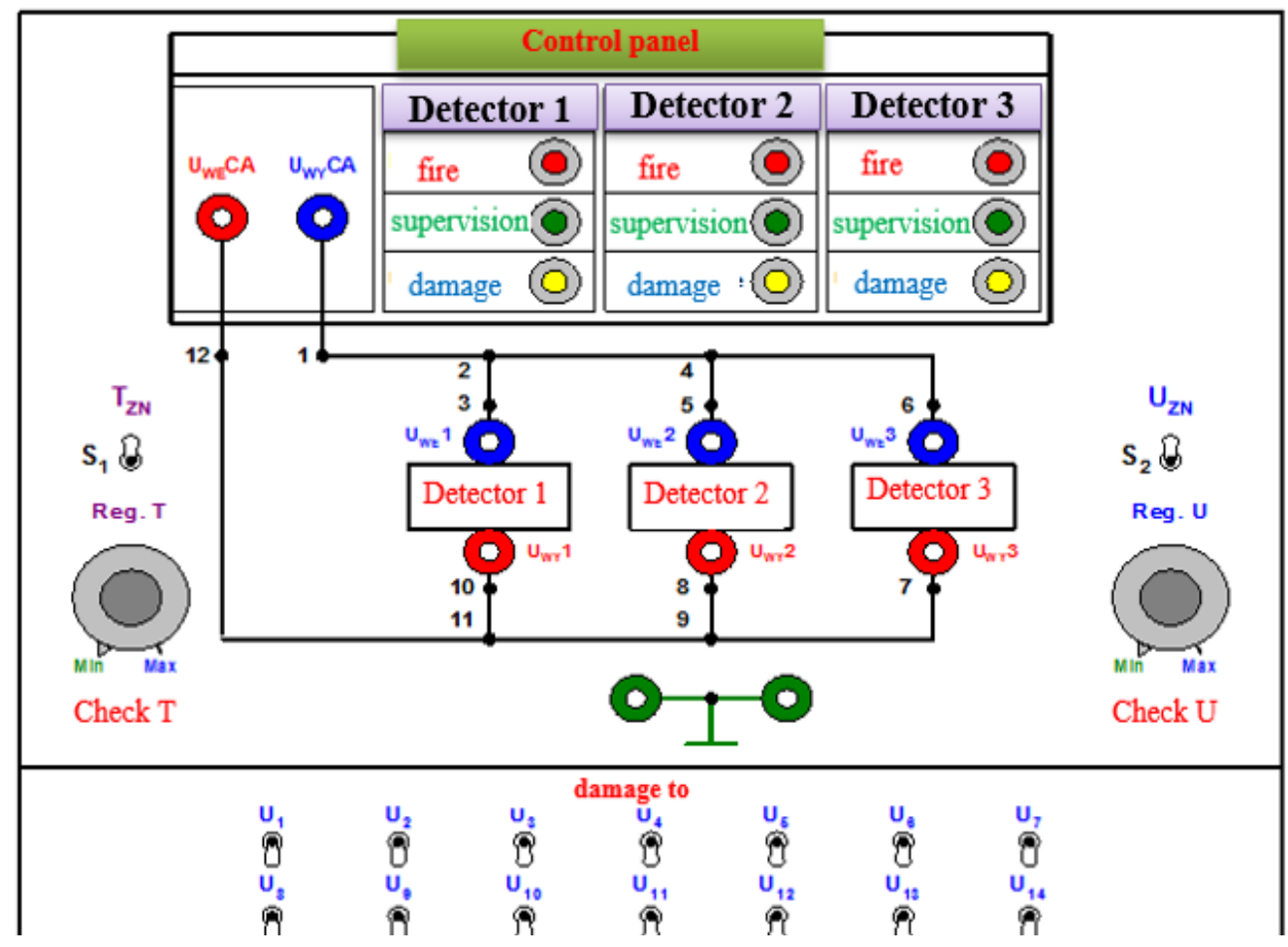

Fig. 7. View of the front panel of the station for diagnosing the fire alarm system

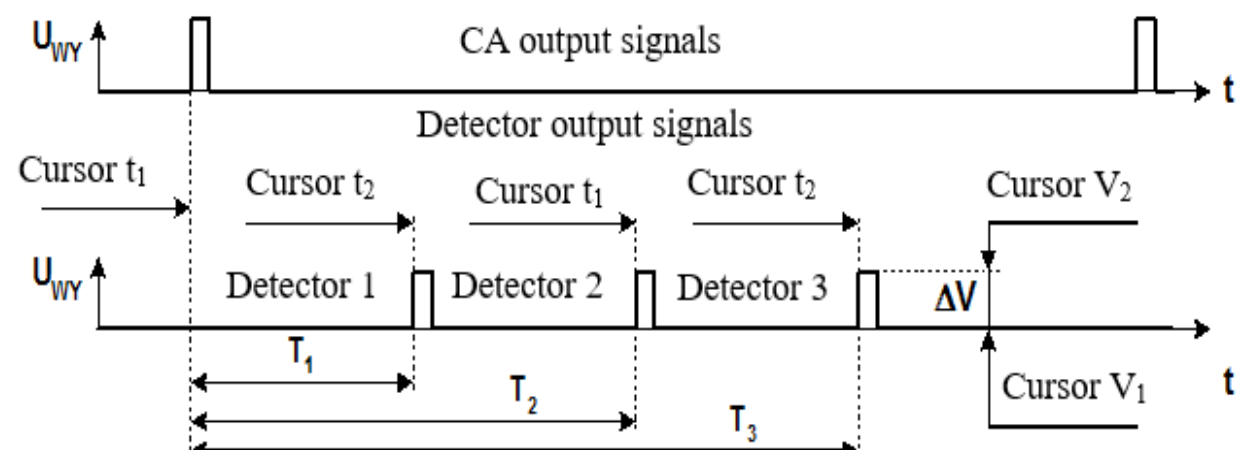

Fig. 8. Measurement of the shift times and amplitude of the detectors' output pulses 


\section{Implementation of example damage to the fire alarm system}

Figures 9 and 10 present a view of the front panel of the fire alarm system model with the information panel related to the technical condition of detectors, the panel with switches to cause damage, and the potentiometer to check the ratings of the amplitude and duration of gates. In Figure 8c), there is a view of the measuring instrument screen (oscilloscope) with the rated position of pulses in the fire alarm system (no damage).

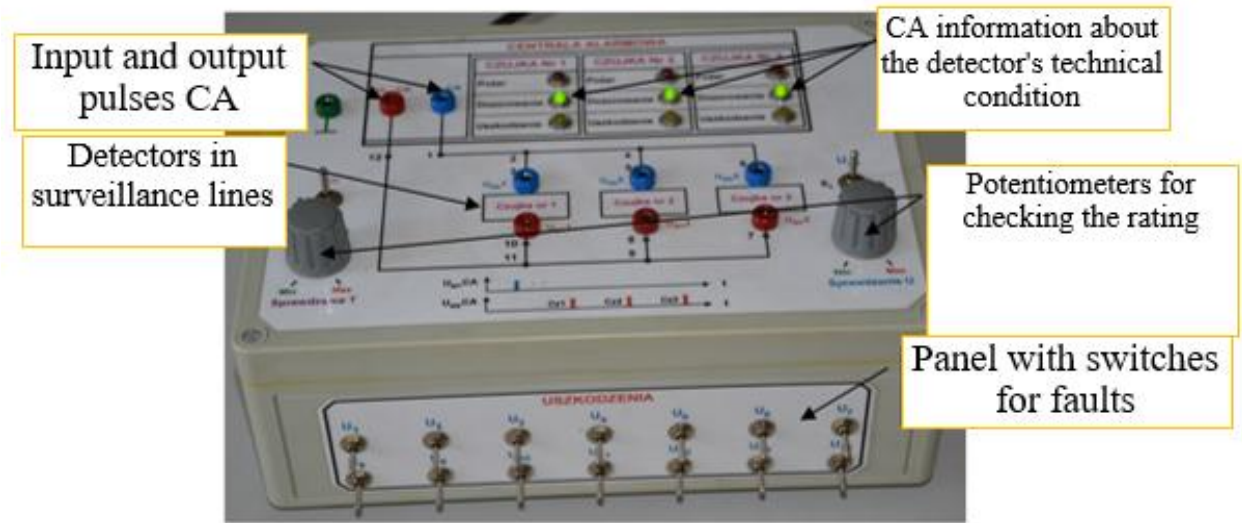

Fig. 9. View of the station - control panel model and 3 lines with detectors in the surveillance state
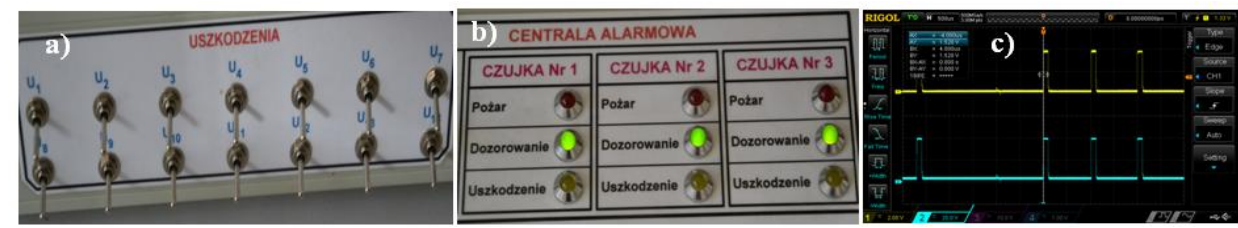

Fig. 10. Panel of damage extortion in the fire alarm system (1-14) (a), control panel of the fire alarm system (b), rated position of pulses in surveillance lines and control panel (c)

Figures 11 and 12 present the implementation of selected damage to the fire alarm system and corresponding imaging on the measuring instrument screen (oscilloscope) used for checking the system state.
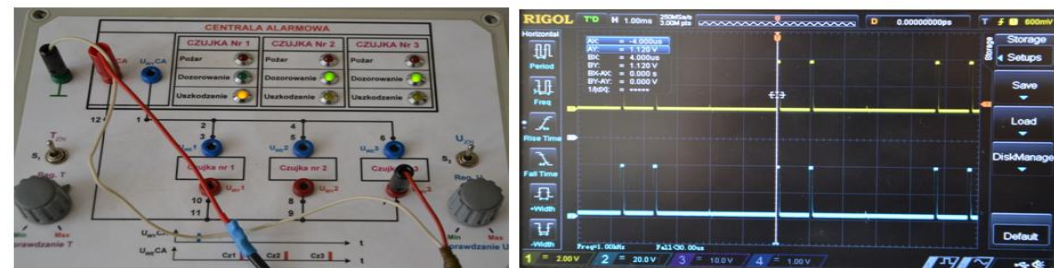

Fig. 11. Activated damage No. 3: view of the control panel indication and imaging on the oscilloscope - a result of the damage identification process 
Teaching methodology of the diagnosing process on the example of the fire... Metodyka nauczania procesu diagnozowania na przykładzie systemu sygnalizacji...
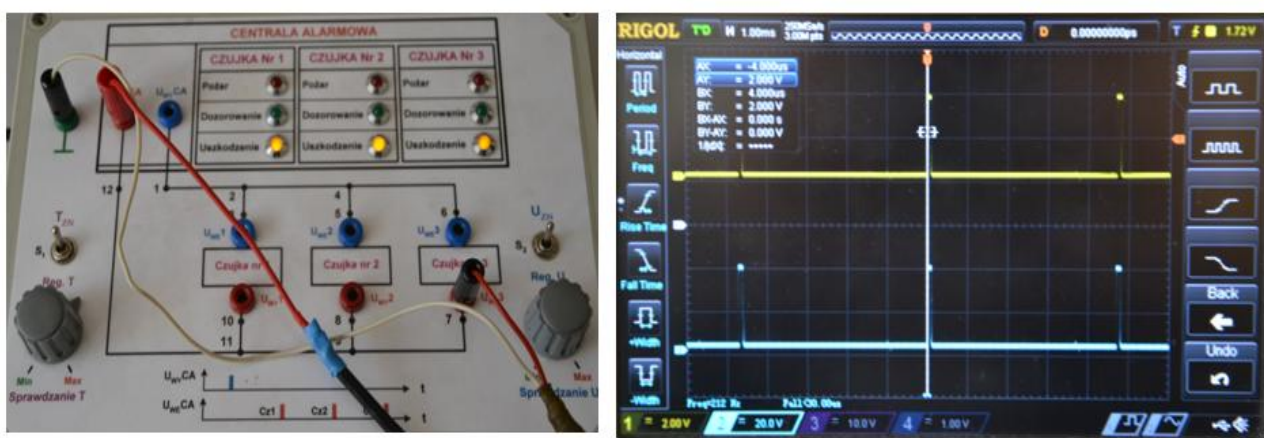

Fig. 12. Activated damage No.: view of the control panel indication and imaging on the oscilloscope - a result of the damage identification process

The students implement the process of diagnosing the technical and functional conditions in the fire alarm system after causing specific damage by the teacher. The diagnostic tables are also useful in this operation (see the sample table No. 5), which students are required to complete with specific entries $[1,2,4,6,11,18,19]$.

Table 5. Diagnostic table for implementation of the check No. $x$.

\begin{tabular}{|c|c|c|}
\hline \multicolumn{2}{|r|}{ Inflicted damage } & Turned on breaker $\mathrm{U}_{\mathrm{y}}$ \\
\hline \multirow{4}{*}{$\frac{7}{\frac{2}{2}}$} & Symptom & $\begin{array}{l}\mathrm{O}_{1} . \text { Yellow LEDs light in the } \\
\text { detectors' channels ... }\end{array}$ \\
\hline & Hypothesis & $\begin{array}{l}\text { No pulses at the output of the control } \\
\text { panel of detectors ... }\end{array}$ \\
\hline & Checking command & $\begin{array}{l}\text { Check } \mathrm{T}_{\mathrm{D}} \text { and } \mathrm{T}_{\mathrm{G}} \text { in the detector's } \\
\text { channel No... }\end{array}$ \\
\hline & $\begin{array}{l}\text { Results of checking } \\
\text { Symptom }\end{array}$ & $\begin{array}{l}\mathrm{O}_{2} . \quad \text { Pulse of the detector } 1 \text { is } \\
\text { outside "Measuring gate" }\end{array}$ \\
\hline \multirow{3}{*}{$\frac{2}{\frac{2}{\pi}}$} & Hypothesis & $\begin{array}{l}\text { Damaged measuring system of the } \\
\text { detectors' output voltage amplitude } \\
\text { in the control panel.............. }\end{array}$ \\
\hline & Checking command & $\begin{array}{l}\text { Check the pulse parameters at the } \\
\text { input of the control panel of the } \\
\text { detectors No. .., .. and .. (detectors } \\
\text { No...)........... }\end{array}$ \\
\hline & $\begin{array}{l}\text { Results of checking } \\
\text { Symptom }\end{array}$ & $\mathrm{O}_{3} . \ldots \ldots \ldots \ldots \ldots \ldots$ \\
\hline & Diagnosis & $\begin{array}{l}\text { Pulse of the detector } 1 \text { is outside } \\
\text { "Measuring gate" }- \text { Damaged } \\
\text { control panel. }\end{array}$ \\
\hline
\end{tabular}




\section{Conclusion}

The paper presents the post and laboratory exercises, developed in the Department of Electronic System Operation of the Faculty of Electronics of Military University of Technology. Also, the teaching process methodology for diagnosing the fire alarm system, was presented in the paper. The pulse amplitude values, their duration, location of measuring gates, etc. correspond to the actual control panel used in the actual conditions. The students' task, during the practical implementation of the laboratory exercise, is to make a diagnosis on the fire alarm system state in the final effect. By using the functional diagram of the fire alarm system (Fig. 3), students specify the type and the cause of damage, and also consolidate knowledge in the scope of general principles for diagnosing - and especially, for the diagnostic deduction on the basis of the observed symptoms of the state of the diagnosed system $[3,5,8,14,16,17,20,21]$. The exercise characterised in the above development constitutes one of several substantively similar laboratory tasks, which are implemented by the students of the Faculty of Electronics of Military University of Technology within the framework of, among others, the subject "Operation of safety systems" and "Fundamentals of system operation".

\section{References}

[1] Będkowski L., Dąbrowski T.: Podstawy eksploatacji, cz. II, Podstawy niezawodności eksploatacyjnej. Warszawa: Wojskowa Akademia Techniczna, 2006.

[2] Dąbrowski T., Paś J., Olchowik W., Rosiński A., Wiśnios M.: Podstawy eksploatacji systemów, Laboratorium. WAT Warszawa 2014

[3] Burdzik R., Konieczny Ł., Figlus T.: Concept of on-board comfort vibration monitoring system for vehicles. J. Mikulski (Ed.): Activities of Transport Telematics, TST 2013, CCIS 395. Springer, Heidelberg 2013. pp. 418-425.

[4] Dyduch J., Paś J., Rosiński A.: Podstawy eksploatacji transportowych systemów elektronicznych. Wydawnictwo Politechniki Radomskiej, Radom 2011.

[5] Kołowrocki K., Soszyńska-Budny J.: Reliability and safety of complex technical systems and processes. Springer, London 2011

[6] Żółtowski B., Niziński S.: Modelowanie procesów eksploatacji maszyn, AT-R 2002

[7] Paś J., Dąbrowski T.: Metodyka nauczania diagnozowania systemów bezpieczeństwa na przyktadzie systemów sygnalizacji włamania $i$ pożaru, Diagnostyka, PTDT, Nr 2(46)/ 2008, pp. 101-104.

[8] Laskowski, D., Lubkowski, P., Pawlak, E., Stańczyk, P.: Anthropotechnical systems reliability. In: the monograph „Safety and Reliability: Methodology and Applications - Proceedings of the European Safety and Reliability Conference ESREL 2014”, editors: Nowakowski T., Młyńczak M., Jodejko- 
Teaching methodology of the diagnosing process on the example of the fire...

Metodyka nauczania procesu diagnozowania na przykładzie systemu sygnalizacji...

Pietruczuk A. \&Werbińska-Wojciechowska S. CRC Press/Balkema, London, 2015, pp. 399-407.

[9] Paś J.: Eksploatacja elektronicznych systemów transportowych. Uniwersytet Technologiczno - Humanistyczny, Radom 2015.

[10] Rosiński A.: Modelowanie procesu eksploatacji systemów telematyki transportu. Oficyna Wydawnicza Politechniki Warszawskiej, Warszawa 2015.

[11] Siergiejczyk M., Paś J., Rosiński A.: Issue of reliability-exploitation evaluation of electronic transport systems used in the railway environment with consideration of electromagnetic interference. IET Intelligent Transport Systems 2016, doi: 10.1049/iet-its.2015.0183.

[12] Siergiejczyk M., Paś J., Rosiński A.: Train call recorder and electromagnetic interference. Diagnostyka 2015, vol. 16, no. 1, pp. 19-22.

[13] Siergiejczyk M., Rosiński A., Paś J.: Analysis of unintended electromagnetic fields generated by safety system control panels. Diagnostyka 2016, vol. 17, no. 3, pp. 35-40.

[14] Duer S., Zajkowski K., Duer R., Paś J.: Designing of an effective structure of system for the maintenance of a technical object with the using information from an artificial neural network, Neural Computing \& Applications. Vol. 23, No. 3-4, pp. 913-925, 2013.

[15] Zajkowski K., The method of solution of equations with coefficients that contain measurement errors, using artificial neural network, Neural Computing and Applications, Volume: 24, Issue: 2, pp. 431-439, 2014.

[16] Stawowy M., Dziula P.: Comparison of uncertainty multilayer models of impact of teleinformation devices reliability on information quality. In: "Proceedings of the European Safety and Reliability Conference ESREL 2015", editors: L. Podofillini, B. Sudret, B. Stojadinovic, E. Zio, W. Kröger. CRC Press/Balkema, 2015. pp. 2685-2691.

[17] Duer S.: Expert knowledge base to support the maintenance of a radar system, Defence Science Journal, Vol. 60, No. 5, pp. 531-540, 2010.

[18] Sumila M.: Selected aspects of message transmission management in ITS systems. In: the monograph „Telematics in the transport environment”, editors: Jerzy Mikulski, given as the monographic publishing series "Communications in Computer and Information Science”, Vol. 329. SpringerVerlag, Berlin Heidelberg 2012, pp. 141-147.

[19] Duer S., Duer R.: Diagnostic system with an artificial neural network which determines a diagnostic information for the servicing of a reparable technical object, Neural Computing \& Applications, Vol. 19, No. 5, pp. 755-766, 2010.

[20] Smyczek J., Zajkowski K: Simulation of overvoltages for switching off lagging load from mains. Conference: 2nd International Industrial Simulation Conference Location: Malaga, SPAIN Date: 2004, pp. 278-281 Published: 2004.

[21] Wiśnios M., Dąbrowski T., Bednarek M.: Metoda zwiększania poziomu bezpieczeństwa zapewnianego przez system biometrycznej kontroli dostęu. Przegląd Elektrotechniczny 2015, nr 10, s. 229-232. 


\section{METODYKA NAUCZANIA PROCESU DIAGNOZOWANIA NA PRZYKLADZIE SYSTEMU SYGNALIZACJI POŻARU}

\section{Ogólna charakterystyka systemów sygnalizacji pożaru}

W sytuacji zwiększających się wymagań użytkowników budynków odnośnie ich bezpieczeństwa, funkcjonalności i kosztów eksploatacji obiekty budowlane wyposaża się w techniczne systemy bezpieczeństwa, w tym systemy sygnalizacji pożaru (SSP) $[2,4,9,10]$. Bezpieczeństwo pożarowe jest zagadnieniem złożonym, uwzględniającym wiele czynników zarówno budowlanych, jak i instalacyjnych (technicznych). SSP jest podstawowym systemem bezpieczeństwa, chroniącym życie i zdrowie ludzi. Podstawowym elementem, który decyduje o wykryciu pożaru są urządzenia detekcyjne (czujki) reagujące na zmiany wielkości fizycznych towarzyszących pożarom. Niekontrolowany pożar może przyczynić się do istotnych strat materialnych, jak również może stanowić bezpośrednie zagrożenie zdrowia i życia. W pewnej klasie obiektów wielko kubaturowych (np. w budynkach handlowych, teatrach, kinach, szpitalach, dworcach kolejowych) stosowanie systemów SSP jest konieczne a zarazem obowiązkowe (rys. 1). W tych budynkach istnieje potrzeba nie tylko wykrywania pożaru ale także lokalizowania jego źródła $[9,10,11]$. To wymaganie można spełnić poprzez odpowiednie adresowanie czujek pożarowych.

Ze względu na typ SSP rozróżnia się następujące typy adresowania:

- adresowanie grupowe - polega na wskazaniu linii dozorowej, do której czujka przesyła sygnał alarmu pożarowego. Umożliwia to identyfikację zagrożonego obszaru-strefy, w której czujka zareagowała na źródło pożaru. Numer linii dozorowej to także numer strefy, którą może być np.: korytarz, kondygnacja lub np. grupa nadzorowanych pomieszczeń;

- adresowanie indywidualne - dotyczy pojedynczych czujek, grup czujek oraz elementów sterujących, zainstalowanych w linii dozorowej przyłączonej do centrali alarmowej (CA). Każdy z tych elementów ma przypisany indywidualny adres. Umożliwia to identyfikację przez CA miejsca zagrożenia oraz wysyłanie i odbieranie sygnałów $\mathrm{z}$ wybranych urządzeń (identyfikacja jest funkcją przyjętej powierzchni dozorowania) $[6,7,9,10]$. W sposobie adresowania istnieje możliwość grupowania adresowalnych elementów sieci w specjalne grupy logiczne, składające się z kilku stref dozorowych.

W zależności od metody wymiany informacji między urządzeniami przyłączonymi do magistrali transmisyjnej a centralą alarmową wyróżnia się:

- systemy monologowe, w których czujki zgłaszają się do centrali jedynie w chwili wykrycia pożaru. Nie jest możliwe podłączenie w tych liniach elementów wykonawczych. Przyłączanie urządzeń wykonawczych odbywa się najczęściej poprzez wejścia $\mathrm{w}$ centrali lub za pomocą specjalnych modułów instalowanych w linii;

- systemy dialogowe, w którym element adresowy (np. czujka) przekazuje informacje o swoim stanie (zdatny - niezdatny), np.: w przypadku procedury odpytania ze strony CA. Między elementami SSP występuje wzajemna wymiana informacji. 
Teaching methodology of the diagnosing process on the example of the fire...

Metodyka nauczania procesu diagnozowania na przykładzie systemu sygnalizacji...

Komunikacja pomiędzy elementami SSP może odbywać się w sposób:

- prądowy - czujka wykrywa zagrożenie pożarowe na podstawie nagłego zwiększenia poboru prądu;

- impulsowy - numer adresowy czujki identyfikowany jest przez impuls prądowy czujki. Amplituda impulsu informuje o stanie czujki. Opóźnienie względem momentu aktywacji czujki stanowi informację o chwilowej wartości parametrów pożarowych (systemy analogowe);

- cyfrowy - transmisja polega na sekwencyjnym przesyłaniu zakodowanych według określonego protokołu - pakietów danych cyfrowych (rys. 2)[12,13,15]. Możliwa jest identyfikacja czujki lub innego elementu systemu poprzez określenie rodzaju oraz aktualnej wartości parametrów zagrożenia wykrywanych przez dany typ czujki $[4,7,12,13]$.

$\mathrm{Na}$ rysunku 1 przedstawiony jest schemat SSP z zaznaczonym fragmentem, który jest wykorzystywany w procesie nauczania diagnozowania. Do CA podłączona jest jedna linia dozorowa $\mathrm{z}$ izolatorem zwarć oraz ręcznym ostrzegaczem pożarowym (ROP).

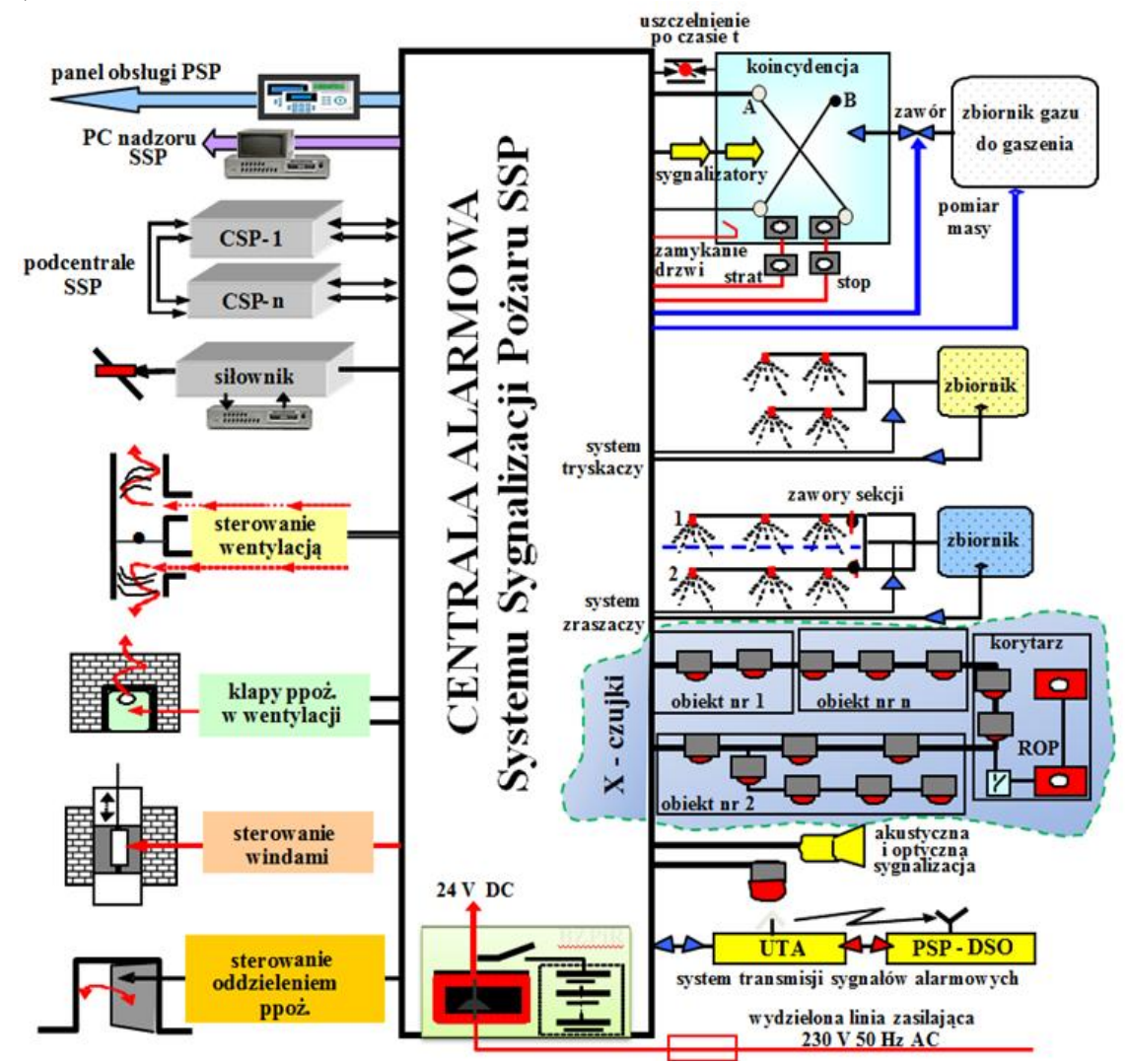

Rys. 1. Zintegrowany system sygnalizacji pożarowej (SSP) wykorzystywany $w$ budynku inteligentnym $(X-c z u j k i$, linie dozorowe wykorzystywane $w$ procesie nauczania diagnozowania) 
Istnienie dużego zbioru dostępnych stanów w systemach ppoż. oraz potrzeba wskazania występującego zagrożenia ppoż. w ochranianym obiekcie $\mathrm{z}$ dokładnością do pojedynczego pomieszczenia wymusiło stosowanie adresowalnych czujek reagujących na powstanie pożaru. Ważną cechą urządzeń sygnalizacji pożarowej jak i innych systemów alarmowych jest sposób komunikacji między czujkami a centralą.

W systemie monologowym informacja przesyłana jest $\mathrm{w}$ jednym kierunku, oznacza to, że detektory zgłaszają się do centrali z chwilą wykrycia alarmu. Istnieje możliwość wystąpienia kolizji w przypadku równoczesnego zgłoszenia się dwóch alarmów, dlatego w celu wyelimowania tego zjawiska stosowane jest losowanie momentu zgłoszenia się pobudzonej czujki. Przy komunikacji dialogowej występuje komunikacja czujki z centralą dwukierunkowo. Centrala SSP inicjuje „rozmowę” z poszczególnymi detektorami, a następnie te ostatnie przekazują informacje, w których zawarty jest nr detektora jak i dane o stanie otoczenia wokół nich. Pozwala to na wyemitowanie sytuacji konfliktowych, fałszywych alarmów, a także na sterowanie adresowalnymi urządzeniami zainstalowanymi na liniach dozorowych.

W systemach SSP można wyodrębnić następujące sposoby adresacji czujek:

- adresacja czujek na zasadzie pomiaru stopnia podziału dzielników napięcia monolog;

- adresacja na zasadzie transmisji cyfrowej - monolog;

- adresowanie w systemie impulsowym - dialog;

- adresowanie w systemie impulsowym z podziałem czasowym - monolog;

- adresowanie w systemie cyfrowym - dialog.

Ciągłe zmiany parametrów czujek i centrali alarmowej spowodowane są między innymi procesami starzenia i zużycia. Zmiany te stwarzają duże trudności przy obliczaniu niezawodności systemów pożarowych ze względu na stochastyczny i bliżej nieokreślony charakter naturalnych zmian parametrów elementów. Rozrzut produkcyjny określa tzw. niezawodność początkową, nazywaną niekiedy w literaturze niezawodnością schematową. Wystąpienie uszkodzenia związanego z procesami starzenia powoduje wystąpienie niezdatności starzeniowej, która zgodnie z Polską Normą PN-90 /N-04002 (Diagnostyka techniczna - Terminologia ogólna) definiowana jest następująco: „niezdatność starzeniowa - niezdatność wynikająca z uszkodzenia, którego prawdopodobieństwo zwiększa się z upływem czasu jako wynik wewnętrznych procesów zachodzących w obiekcie" w tym wypadku ppoż. systemie alarmowym.

Parametry wyjściowe każdego ppoż. systemu alarmowego określane są poprzez:

- parametry elementów z których ten system jest zbudowany;

- wewnętrzną strukturę połączeń systemu alarmowego (centrala - czujki zasilanie - sygnalizatory, itd.). 
Teaching methodology of the diagnosing process on the example of the fire...

Metodyka nauczania procesu diagnozowania na przykładzie systemu sygnalizacji...

Między parametrami wyjściowymi Đ ppoż. systemu alarmowego, a parametrami $\mathrm{x}_{\mathrm{i}}(\mathrm{i}=1,2, . ., \mathrm{N})$ elementów składowych istnieje zależność funkcyjna $\mathrm{\Xi}=\mathrm{f}\left(\mathrm{x}_{1} ; \mathrm{x}_{2} ; . ., \mathrm{x}_{\mathrm{N}}\right)$ która dla przyrostów względnych przyjmuje postać

$$
\delta Đ=\mathrm{f}_{1}\left(\delta \mathrm{x}_{1} ; \delta \mathrm{x}_{2} ; \ldots, \delta \mathrm{x}_{\mathrm{N}}\right)
$$

Zależność (1) dla małych $\delta \mathrm{x}_{\mathrm{i}}(\mathrm{i}=1, \mathrm{~N})$ można przedstawić w innej postaci

$$
\delta Đ=\xi \mathrm{x}_{1}+\xi \mathrm{x}_{2}+\ldots+\xi \mathrm{x}_{\mathrm{N}}
$$

gdzie

$$
\delta Đ=\frac{Đ-\bigoplus_{\mathrm{n}}}{\bigoplus_{\mathrm{n}}} ; \quad \delta x_{i}=\frac{\mathrm{x}_{\mathrm{i}}-\mathrm{x}_{\mathrm{in}}}{\mathrm{x}_{\mathrm{in}}} ; \quad \xi_{i}=\frac{\delta \mathrm{D}}{\delta \mathrm{x}_{\mathrm{i}}}
$$

oznaczenia: $\mathrm{n}$ - wartości nominalne odpowiednich parametrów ppoż. systemu alarmowego; $\xi$ - współczynniki wpływu, które określają przyrost $\delta Ð$ parametru wyjściowego, spowodowany przyrostem $\delta x_{i}$ parametru $\mathrm{i}$ - tego elementu wchodzącego w skład ppoż. systemu alarmowego.

Współczynniki wpływu $\xi_{\mathrm{i}}$ zależą od miejsca elementu w strukturze całego systemu alarmowego (np. jeden z rezystorów polaryzujących bazę tranzystora w układzie wzmacniacza sygnału znajduje się w czujce ppoż., a rezystor parametryzujący linię dozorową znajduje się w linii podłączonej do centrali alarmowej. Dlatego też współczynniki $\xi_{\mathrm{i}}$ bywają także nazywane współczynnikami położenia.

Do prawidłowej pracy czujek ppoż. i znajdujących się $w$ ich gniazdach elektronicznych systemów adresacji wymagany jest odpowiedni poziom napięcia zasilającego. W tab. 1 przedstawiono dopuszczalne poziomy napięć zasilających najczęściej wykorzystywanych czujek instalowanych w ppoż. systemach alarmowych.

Tab. 1. Dopuszczalne poziomy napięć zasilajacych czujki instalowane w ppoż. systemach alarmowych.

\begin{tabular}{|l|c|c|c|c|}
\hline \multicolumn{1}{|c|}{ Typ czujki } & DF1101-Ex $^{1}$ & DLO1191 $^{2}$ & G-3840 & $R O P-38 A^{4}$ \\
\hline Napięcie pracy $[\mathrm{V}]$ & $16 \div 28$ & $16,5 \div 24$ & $19,5 \div 24$ & $17 \div 24$ \\
\hline Prąd dozorowania $[\mu \mathrm{A}]$ & 500 & 150 & 80 & 80 \\
\hline
\end{tabular}

Oznaczenia:

DF1101-Ex ${ }^{1}$ - czujka płomienia adresowalna firmy SIEMENS,

DLO1191 ${ }^{2}$ - adresowalna liniowa czujka dymu firmy SIEMENS,

G-3840 3 - gniazdo adresowalne systemu ALFA 3800 /produkcja Polon - Alfa/,

ROP $-38 \mathrm{~A}^{4}$ - ręczny ostrzegacz pożarowy (adresowalny systemu ALFA 3800). 
Dopuszczalne zakresy zmian napięcia zasilającego czujki i systemy adresacji zawierają się w granicach $(16 \div 28) \mathrm{V}$ (najgorszy przypadek), przy dopuszczalnej temperaturze pracy wynoszącej $(-25 \div+60){ }^{0} \mathrm{C}-$ rys. 2 . Zmiana napięcia zasilania oraz temperatury powoduje zmianę parametrów sygnałów adresacji wysyłanych $\mathrm{z}$ czujki do centrali alarmowej. W tab. 2, 3 oraz 4 przedstawiono wpływ w/w zmian na odpowiedzi generowane przez czujki znajdujące się w systemie alarmowym.

a
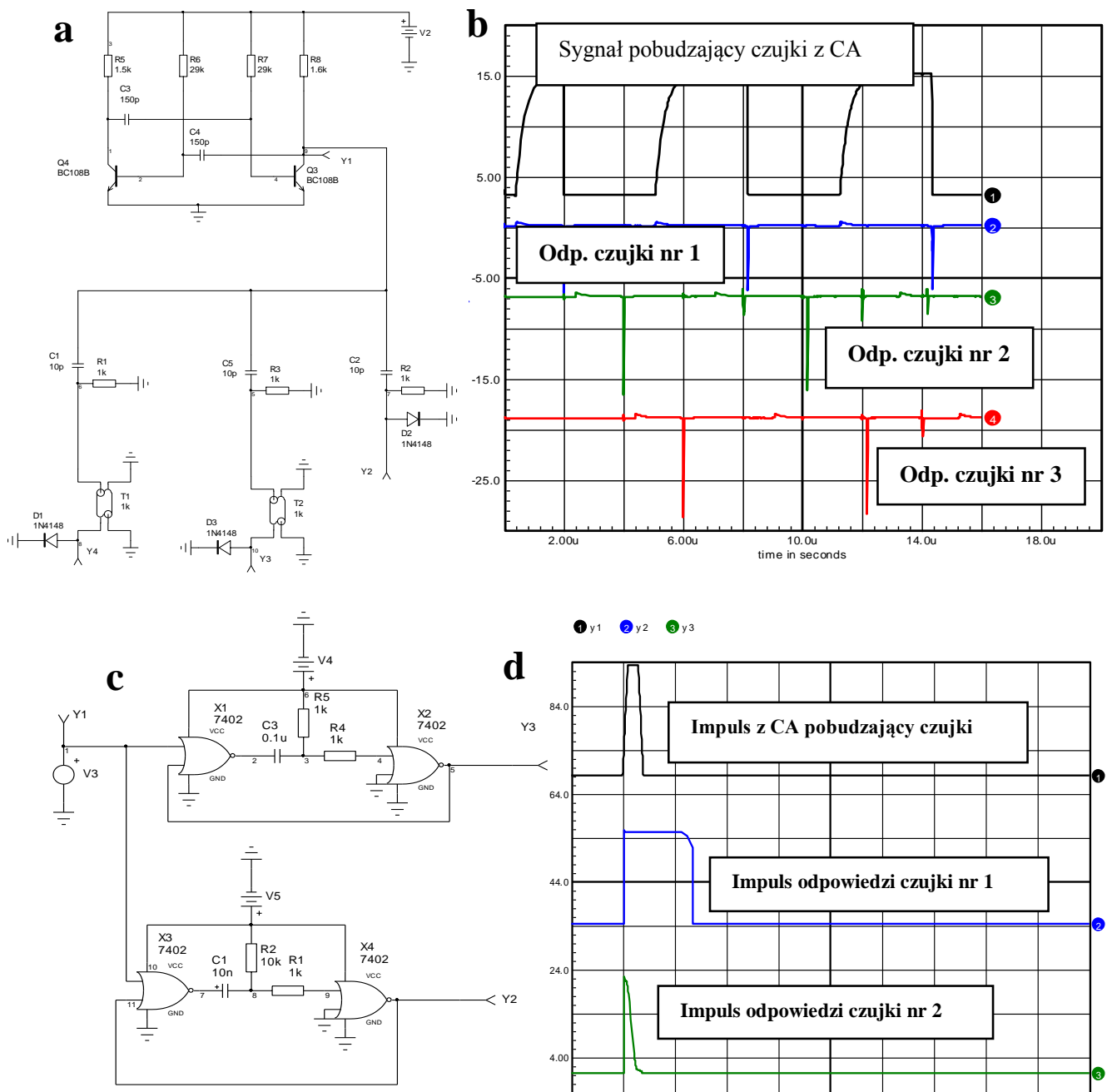

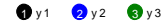

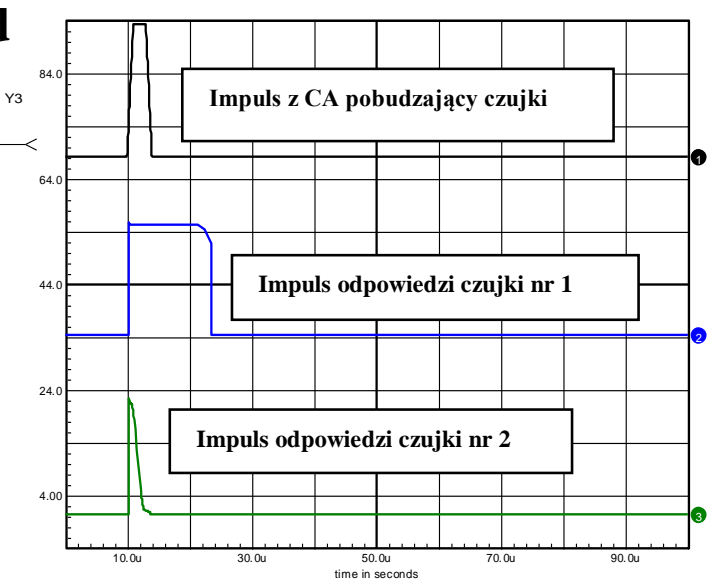

Rys. 2. Przyktadowe sposoby adresowania czujek $w$ systemie bezpieczeństwa $(2 a, 2 c)$ oraz odpowiadajace im przebiegi czasowe generowane $w$ czujkach $(2 b, 2 d)$. 
Teaching methodology of the diagnosing process on the example of the fire...

Metodyka nauczania procesu diagnozowania na przykładzie systemu sygnalizacji...

Tab. 2. Adresowanie czujek na zasadzie pomiaru stopnia podzialu dzielników napięcia - wptyw zmian $U_{z a s}$ na wartość podziatu U (rys. $3 a$ ).

\begin{tabular}{|c|c|c|c|}
\hline $\begin{array}{c}\text { Napięcie } \\
\text { zasilania U[V] }\end{array}$ & $\begin{array}{c}\text { Dzielnik napięcia } \\
\text { U[V] nr 1 }\end{array}$ & $\begin{array}{c}\text { Dzielnik napięcia } \\
\text { U[V] nr 2 }\end{array}$ & $\begin{array}{c}\text { Dzielnik napięcia } \\
\text { U[V] nr 3 }\end{array}$ \\
\hline 16 & 8 & 10,7 & 12 \\
$\mathbf{U}_{\mathrm{zn}}=24$ & 12 & 16 & 18 \\
28 & 14 & 18,7 & 21 \\
\hline
\end{tabular}

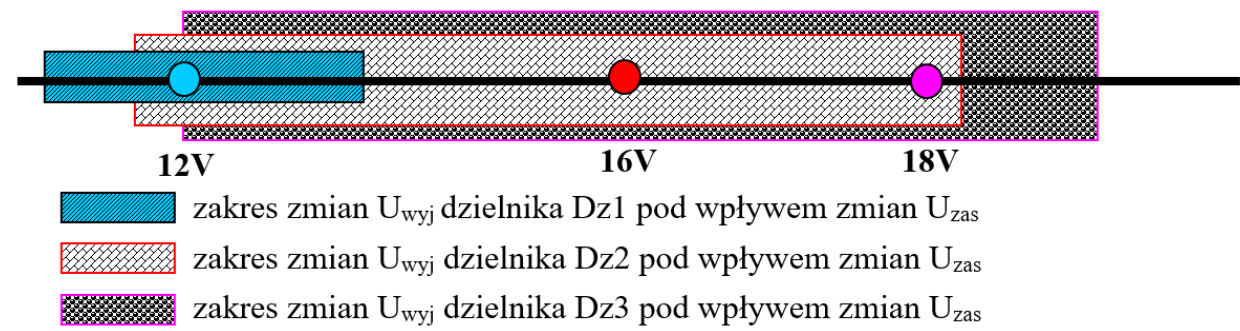

Tab. 3. Adresowanie czujek $w$ systemie impulsowym z podziatem czasowym wplyw zmian $U_{z a s}$ oraz temperatury na wartość czasu trwania $t_{i}$ impulsów wyjściowych czujek nr 2, 3 (schemat połaczeń rys. 3.b).

\begin{tabular}{|c|c|c|c|c|}
\hline \multirow{2}{*}{\begin{tabular}{|c|} 
Zmiana \\
napięcia \\
zasilania \\
U[V] \\
\end{tabular}} & \multirow{2}{*}{$\begin{array}{c}\text { Zmiana } \\
\text { temperatury } \\
\text { pracy czujek }\left[{ }^{0} \mathrm{C}\right]\end{array}$} & \multicolumn{3}{|c|}{$\begin{array}{c}\text { Zamiana czasu trwania } t_{i}[\mu \mathrm{s}] \text { impulsów } \\
\text { odpowiedzi generowanych przez czujki } 2,3\end{array}$} \\
\hline & & $\mathrm{Czu}$ & ka nr 2 & Czujka nr 3 \\
\hline \multirow{3}{*}{16} & -25 & & 39108 & 1,98911 \\
\hline & +27 & 0,9 & 31997 & 1,98198 \\
\hline & +60 & & 7871 & 1,97787 \\
\hline \multirow{3}{*}{$\mathrm{U}_{\mathrm{zn}}=24$} & -25 & & 3695 & 2,03839 \\
\hline & +27 & & 1843 & 2,01876 \\
\hline & +60 & & 9206 & 1,99849 \\
\hline \multirow{3}{*}{28} & -25 & & 39108 & 2,01411 \\
\hline & +27 & & 0698 & 1,95698 \\
\hline & +60 & & 7871 & 1,95287 \\
\hline \multicolumn{4}{|c|}{ Czujka nr 2} & Czujka nr 3 \\
\hline \multirow{2}{*}{\multicolumn{3}{|c|}{ 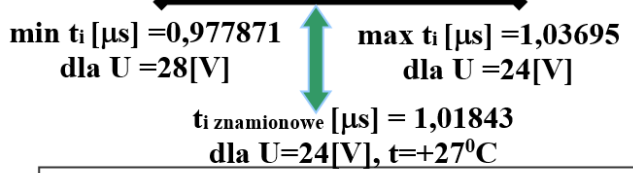 }} & $\min t_{i}[\mu s]=1,95287$ & 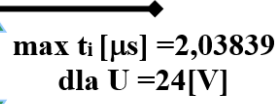 \\
\hline & & & \multicolumn{2}{|c|}{ 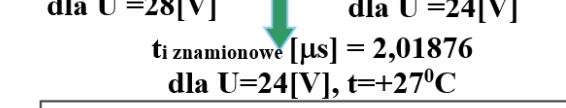 } \\
\hline \multicolumn{3}{|c|}{ Zmiana $w$ stosunku do $t_{1 \text { zanamionowe }}$} & \multicolumn{2}{|c|}{ 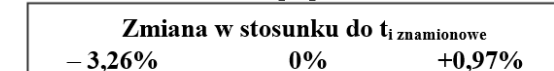 } \\
\hline
\end{tabular}


Tab. 4. Adresowanie czujek $w$ systemie impulsowym - wptyw zmian napięcia zasilającego oraz temperatury na wartość czasu trwania $t_{i}$ impulsów wyjściowych czujek $n r$ 1, 2 (schemat połaczeń rys. 3.c).

\begin{tabular}{|c|c|c|c|}
\hline $\begin{array}{c}\text { Zmiana } \\
\text { napięcia } \\
\text { zasilania } \\
\text { U[V] }\end{array}$ & $\begin{array}{c}\text { Zmiana } \\
\text { temperatury } \\
\text { pracy czujek }\left[{ }^{0} \mathrm{C}\right]\end{array}$ & \multicolumn{2}{|c|}{$\begin{array}{c}\text { Zmaiana czasu trwania } \mathrm{t}_{\mathrm{i}}[\mu \mathrm{s}] \text { impulsów } \\
\text { odpowiedzi generowanych przez czujki 1,2 }\end{array}$} \\
\cline { 3 - 4 } & -25 & 14,0806 & Czujka nr 1 \\
\cline { 2 - 4 } & +27 & 13,4965 & 2,57144 \\
\cline { 2 - 4 } & +60 & 13,8889 & 2,92067 \\
\hline \multirow{3}{*}{$\mathrm{U}_{\text {znam }}=24$} & -25 & 14,2488 & 3,22735 \\
\cline { 2 - 4 } & +27 & 13,8859 & 0,90855 \\
\cline { 2 - 4 } & +60 & 13,2540 & 1,16986 \\
\hline \multirow{3}{*}{28} & -25 & 14,1160 & 1,53392 \\
\cline { 2 - 4 } & +27 & 13,6008 & 0,509341 \\
\cline { 2 - 4 } & +60 & 13,5369 & 0,791544 \\
\hline
\end{tabular}

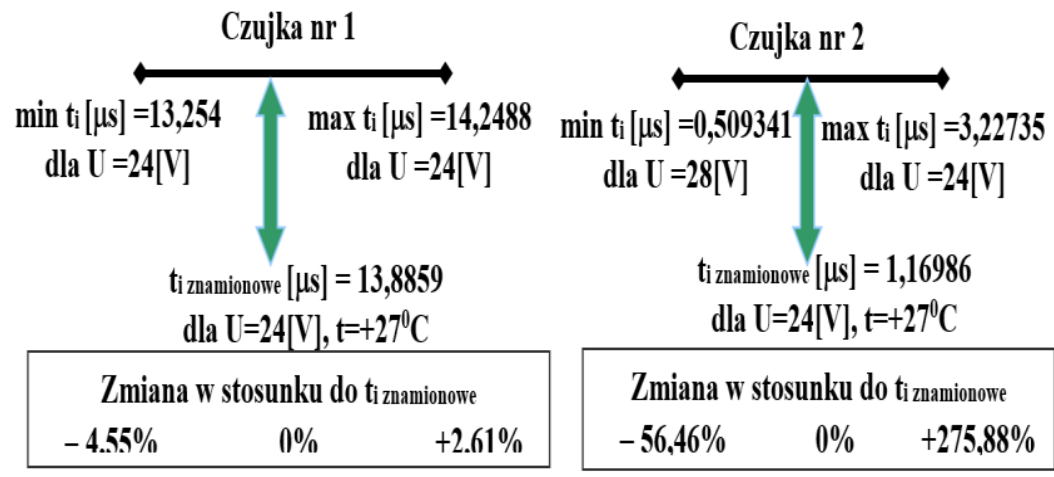

Adresowanie czujek w systemach bezpieczeństwa jest bardzo ważnym problemem technicznym gdyż należy zapewnić odpowiednie rozwiązanie do zmieniających się warunków eksploatacyjnych systemu bezpieczeństwa - rys. 3. Aby adresowanie było prawidłowe muszą istnieć określone marginesy bezpieczeństwa zakresów napięcia poszczególnych czujek. Adresowanie czujek w systemie impulsowym o krótkich czasach trwania obarczone jest wadą dużych zmian czasu trwania impulsu (tab. 4 - czujka nr 2). W tym przypadku stosowanie przebiegów impulsowych o dłuższym czasie trwania (tab. 4 - czujka $\mathrm{nr}$ 1) zwiększa się stabilność adresowania czujki. 
Teaching methodology of the diagnosing process on the example of the fire... Metodyka nauczania procesu diagnozowania na przykładzie systemu sygnalizacji...

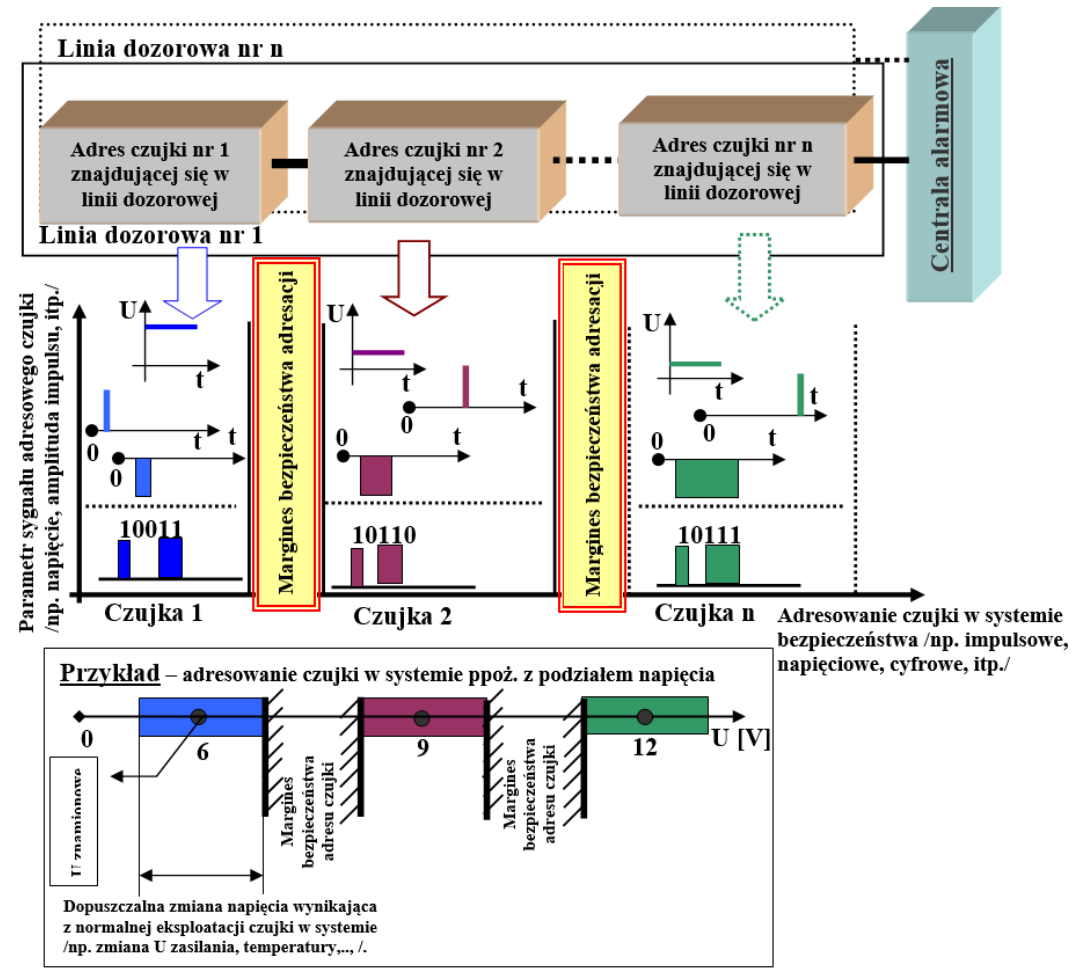

Rys. 3. Wybrane sposoby adresowania czujek w ppoż. systemie bezpieczeństwa

\section{Model laboratoryjny SSP z linami dozorowymi}

Na Wydziale Elektroniki Wojskowej Akademii Technicznej prowadzone są studia o specjalności „Inżynieria Systemów Bezpieczeństwa”. Podczas zajęć ze studentami z przedmiotu „Eksploatacja systemów bezpieczeństwa” na siódmym semestrze prowadzone są ćwiczenia laboratoryjne, które obejmują zagadnienia diagnozowania. Stanowisko laboratoryjne przedstawia prosty model fizyczny układu sygnalizacji pożaru składający się $\mathrm{z}$ centrali alarmowej z jedną linią dozorowania stanu chronionych pomieszczeń - rys. 4 [7]. W linii dozorowania znajdują się trzy czujki pracujące w systemie impulsowym z podziałem czasowym. Ogólny schemat SSP przedstawiono na rysunku 5.

Po wysłaniu przez centralę impulsu, czujka generuje impuls z opóźnieniem czasowym $T_{i}$ zależnym od numeru czujki. $T_{i}=T_{1}$ lub $T_{2}$, lub $T_{3}$. Po czasie $T_{1}$ czujka nr 1 wysyła do linii dozorowej impuls o wartości zależnym od stanu czujki. W kolejnych przedziałach $T_{2}$ i $_{3}$ impulsy są wysyłane przez czujki nr 2 i 3 . Układy wejściowe centrali kontrolując wartości amplitudy impulsów przy pomocy komparatorów drabinkowych $\mathrm{w}$ wyznaczonych przedziałach czasowych identyfikują stan poszczególnych czujek. W dalszej części artykułu przedziały czasowe nazywane są „bramkami pomiarowymi”. Usytuowanie impulsów i bramek pomiarowych przedstawiono na rysunku 6. 


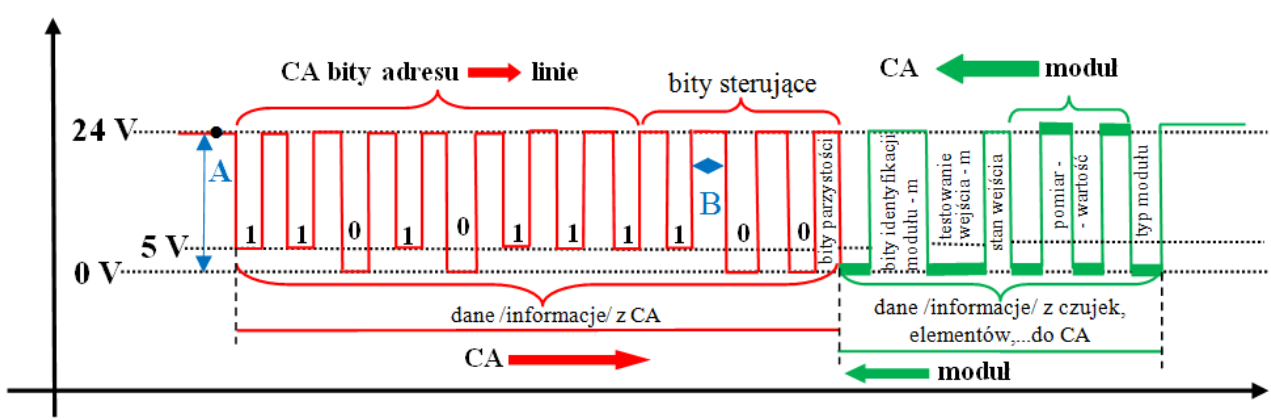

Rys. 4. System dialogowy w SSP - wymiana informacji CA - element, urzadzenie, czujka na linii dozorowej (oznaczenia: A - pomiar wartości napięcia impulsów,

$B$ - pomiar czasu trwania impulsu - bramki realizowane w ćwiczeniu laboratoryjnym)

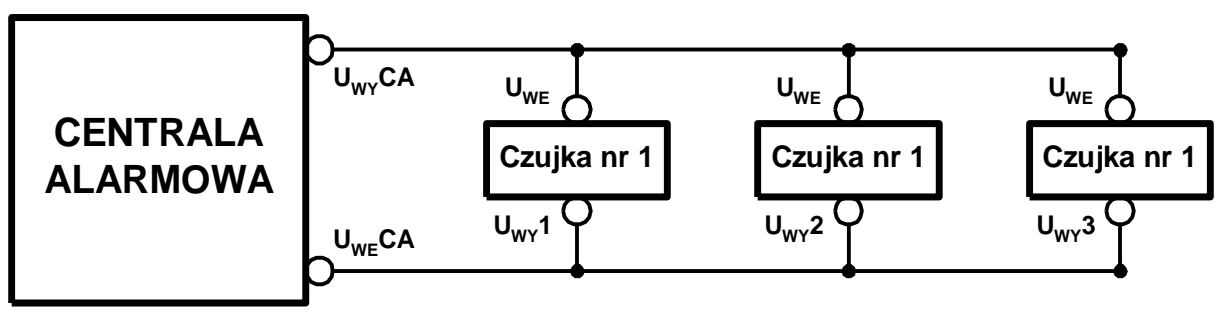

Rys. 5. Uproszczony schemat diagnozowanego fragmentu SSP

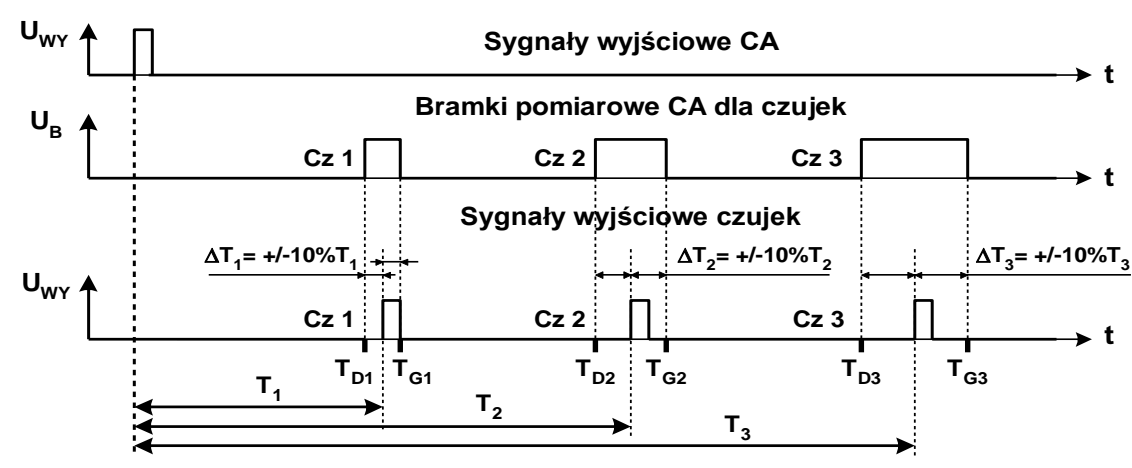

Rys. 6. Impulsy wyjściowe centrali alarmowej i czujek

Oznaczenia na rys. 6. :

- $\mathrm{T}_{1}, \mathrm{~T}_{2}, \mathrm{~T}_{3}$ - czasy przesunięcia czoła impulsów wyjściowych czujek;

- $\Delta \mathrm{T}$ - dopuszczalny zakres przesunięcia impulsu wyjściowego czujki;

- $\mathrm{T}_{\mathrm{D}}$ - dolna granica przesunięcia impulsu wyjściowego czujki;

- $\mathrm{T}_{\mathrm{G}}$ - górna granica przesunięcia impulsu wyjściowego czujki. 
Teaching methodology of the diagnosing process on the example of the fire...

Metodyka nauczania procesu diagnozowania na przykładzie systemu sygnalizacji...

Centrala rozróżnia trzy wartości amplitudy impulsów wyjściowych z czujek, które odzwierciedlają: stan uszkodzenia, stan dozorowania i stan alarmu układu sygnalizacji pożaru. Pomiar amplitudy impulsu wyjściowego danej czujki odbywa się tylko wtedy, gdy czoło impulsu pojawia się $\mathrm{w}$ czasie trwania bramki pomiarowej. W innym przypadku układ pomiarowy amplitudy impulsu stwierdza, że amplituda jest równa zeru i centrala generuje sygnał „Uszkodzenie”.

Zestaw stanowiska laboratoryjnego zawiera konstrukcyjnie pulpit sterująco-pomiarowy i oscyloskop cyfrowy. Stanowisko to umożliwia:

- pomiar czasu T przesunięcia impulsów wyjściowych czujek;

- pomiar amplitudy napięcia impulsów wyjściowych czujek;

- pomiar dolnej $\mathrm{T}_{\mathrm{D}}$ i górnej $\mathrm{T}_{\mathrm{G}}$ granicy przesunięcia impulsu wyjściowego danej czujki;

- pomiar granicznych wartości amplitudy napięcia impulsów wyjściowych czujek, przy których następuje zmiana stanu pracy SSP;

- zadawanie uszkodzeń w SSP.

Pulpit sterująco-pomiarowy zawiera:

- modele czujek i centrali alarmowej;

- wyłączniki i przelączniki sterujące pracą stanowiska oraz potencjometry;

- gniazda pomiarowe i diody sygnalizacyjne.

Gniazda pomiarowe umożliwiają obserwację sygnałów centrali i czujek na ekranie oscyloskopu. Wyłączniki z napisem „Uszkodzenia” $\left(\mathrm{U}_{1} \div \mathrm{U}_{14}\right)$ służą do zadawania uszkodzeń. Diody służą do sygnalizacji stanu pracy SSP (zgodnie z opisem na płycie czołowej stanowiska - rys. 7). Do zasilania stanowiska napięciem $230 \mathrm{~V}$ służy podświetlany wyłącznik z napisem ,Sieć".

Układ przesuwania impulsów wyjściowych czujek służy do pomiaru dolnej $T_{D}$ i górnej $\mathrm{T}_{\mathrm{G}}$ granicy przesunięcia impulsu wyjściowego danej czujki. Układ składa się z przełącznika $S_{I}$ z napisami $T_{Z N}$ i Reg. $T$ oraz potencjometru z napisem Sprawdzanie $T$. Gdy przełącznik $\mathrm{S}_{1}$ znajduje się $\mathrm{w}$ położeniu $\mathrm{T}_{\mathrm{ZN}}$, impulsy wyjściowe czujek są przesunięte względem impulsu wyjściowego centrali o wartości znamionowe $T_{1}, T_{2}$ i $T_{3}$ (patrz rys. 6). Po przełączeniu przełącznika $\mathrm{S}_{1} \mathrm{w}$ położenie Reg. T, potencjometrem z napisem Sprawdzanie $T$ można zmieniać położenie impulsów wyjściowych czujek w zakresie $\mathrm{T} \frac{+600}{-500} \mu \mathrm{s}$.

Bramek pomiarowych, w postaci impulsów, nie można obserwować na ekranie oscyloskopu.

Układ pomiaru granicznych wartości amplitudy napięcia impulsów wyjściowych czujek służy do określenia przy jakich wartościach amplitudy następuje zmiana stanu pracy SSP. Układ składa się z przełącznika $\mathrm{S}_{2}$ z napisami $U_{Z N}$ i Reg. $U$ oraz potencjometru z napisem Sprawdzanie $U$. Gdy przełącznik $\mathrm{S}_{2}$ znajduje się w położeniu $U_{Z N}$, do wejścia centrali alarmowej podawane są impulsy wyjściowe czujek. Po przełączeniu przełącznika $\mathrm{S}_{2}$ w położenie Reg. $U$, do wejścia CA podawane jest napięcie stałe. Zmieniając wartość napięcia można określić graniczne wartości amplitudy napięcia impulsów wyjściowych czujek, przy których następuje zmiana stanu pracy SSP, co jest sygnalizowane zapaleniem się odpowiedniej diody. 


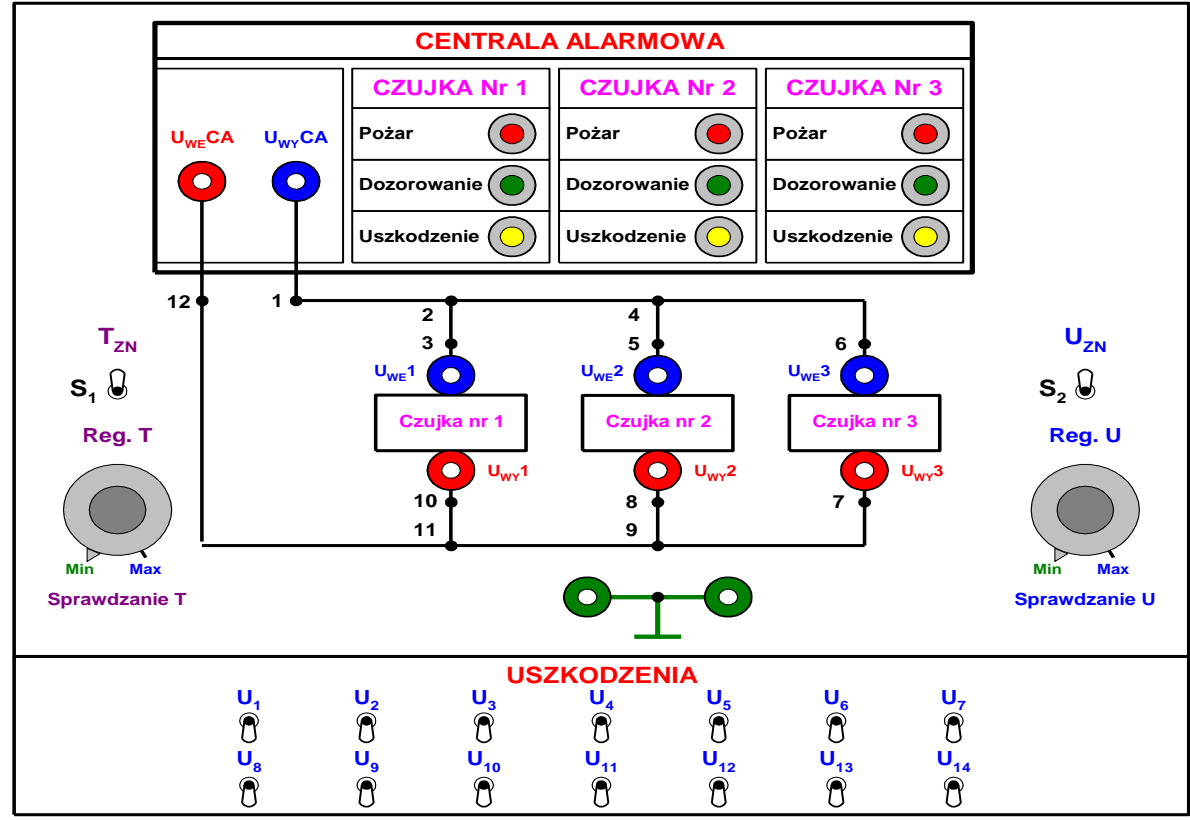

Rys. 7. Widok plyty czolowej stanowiska do diagnozowania SSP

Charakterystyka sygnałów modelu centrali i czujek:

1) Znamionowe przesunięcia sygnałów wyj. czujek: $T_{1}=1 \mathrm{~ms}, T_{2}=2 \mathrm{~ms}, T_{3}=3 \mathrm{~ms}$;

2) Przedziały dopuszczalnych przesunięć impulsów wyj. czujek: $\Delta \mathrm{T}_{1}=+/-100 \mu \mathrm{s}$, $\Delta \mathrm{T}_{2}=+/-200 \mu \mathrm{s}, \Delta \mathrm{T}_{3}=+/-300 \mu \mathrm{s}$

3) Amplituda sygnałów wyjściowych czujek:

- $\mathrm{U}_{\mathrm{WY}}=0 \div 3 \mathrm{~V}$ - stan niezdatności typu przerwa $\mathrm{w}$ obwodzie (tj. między centralą a czujką lub wewnątrz czujki), albo obniżona rezystancja obwodu (prawdopodobieństwo wystąpienia tego uszkodzenia jest bardzo małe) - CA generuje sygnał „Uszkodzenie”;

- $\mathrm{U}_{\mathrm{WY}}=3 \mathrm{~V} \div 6 \mathrm{~V}$ - stan zdatności - CA generuje sygnał „Dozorowanie”- rys. 8;

- $\mathrm{U}_{\mathrm{WY}}>6 \mathrm{~V}$ - stan zdatności - CA generuje sygnał alarmowy „Pożar”.

Na stanowisku można zamodelować następujące uszkodzenia:

- brak sygnału na wejściu czujki (czujek);

- brak sygnału na wyjściu czujki (czujek);

- amplituda sygnału na wyjściu czujki (czujek) większa od znamionowej;

- przesunięcie sygnału na wyjściu czujki (czujek) różne od znamionowego;

- zmiana położenia dolnej $\mathrm{T}_{\mathrm{D}} \mathrm{i}$ górnej $\mathrm{T}_{\mathrm{G}}$ granicy przesunięcia impulsu wyjściowego danej czujki (przesunięcie „bramki pomiarowej” - różne od znamionowego);

- uszkodzony w centrali alarmowej układ pomiaru amplitudy napięcia impulsów wyjściowych czujek (wartość znamionowa oznacza tu przedział wartości odpowiadający stanowi zdatności SSP). 
Teaching methodology of the diagnosing process on the example of the fire... Metodyka nauczania procesu diagnozowania na przykładzie systemu sygnalizacji...

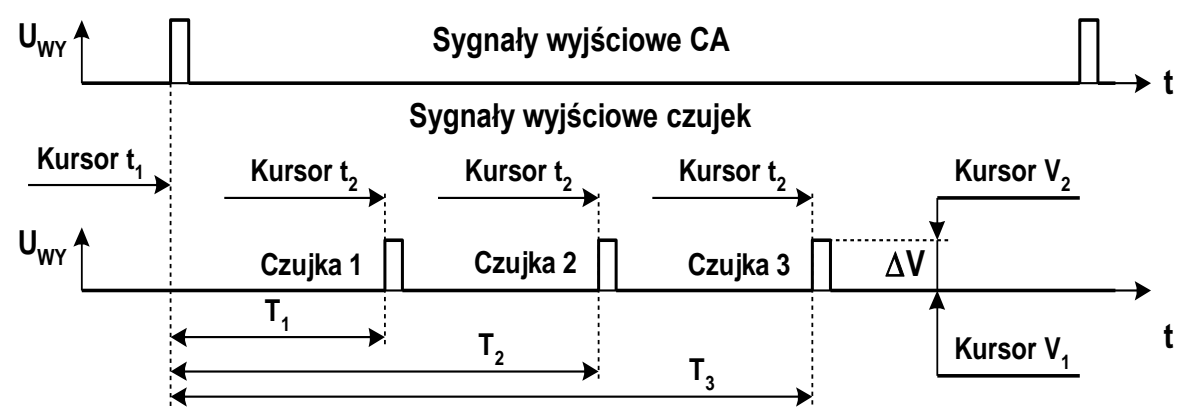

Rys. 8. Pomiar czasów przesunięcia i amplitudy impulsów wyjściowych czujek

\section{Realizacja przykładowych uszkodzeń w systemie SSP}

$\mathrm{Na}$ rysunkach 9 i 10 przedstawiony jest widok płyty czołowej modelu SSP z panelem informacyjnym o stanie technicznym czujek, panelem z przełącznikami do zadawania uszkodzeń oraz potencjometrami do sprawdzania wartości znamionowych amplitudy i czasu trwania bramek. Na rysunku 8c) znajduje się widok ekranu przyrządu pomiarowego (oscyloskopu) przy znamionowym położeniu impulsów w SSP (brak uszkodzeń).

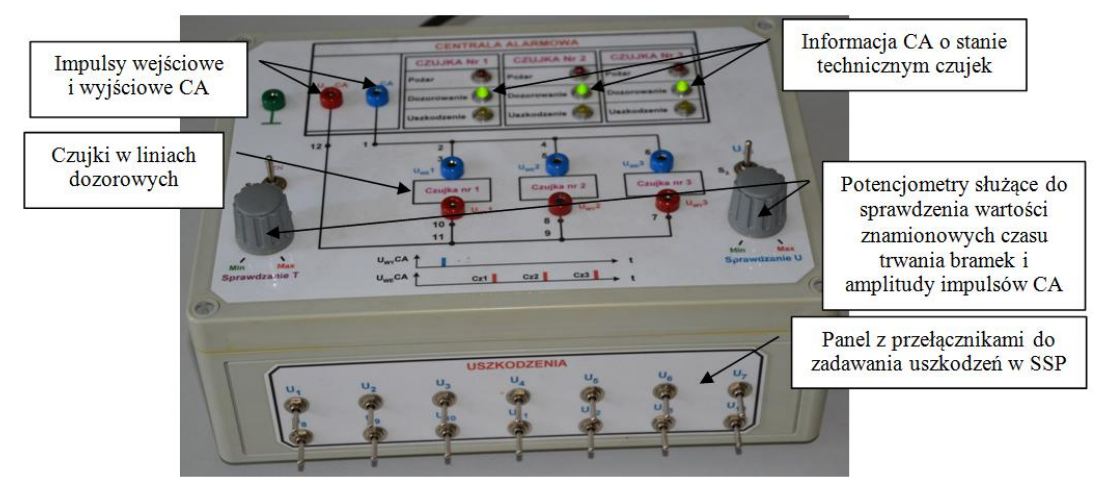

Rys. 9. Widok stanowiska - model CA i 3 linii z czujkami w stanie dozorowania
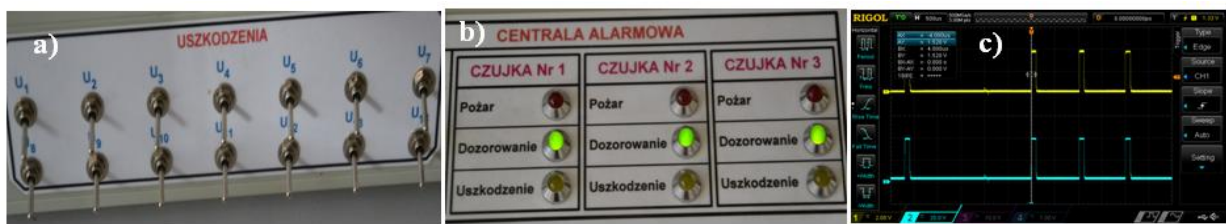

Rys. 10. Panel wymuszeń uszkodzeń w SSP (1-14) (a), panel CA SSP (b), znamionowe położenie impulsów w liniach dozorowych $i$ CA (c) 
Rysunki11 i 12 przedstawiają realizację wybranych uszkodzeń w systemie SSP oraz odpowiadające im zobrazowania na ekranie przyrządu pomiarowego (oscyloskopu) wykorzystywanego do sprawdzenia stanu systemu.
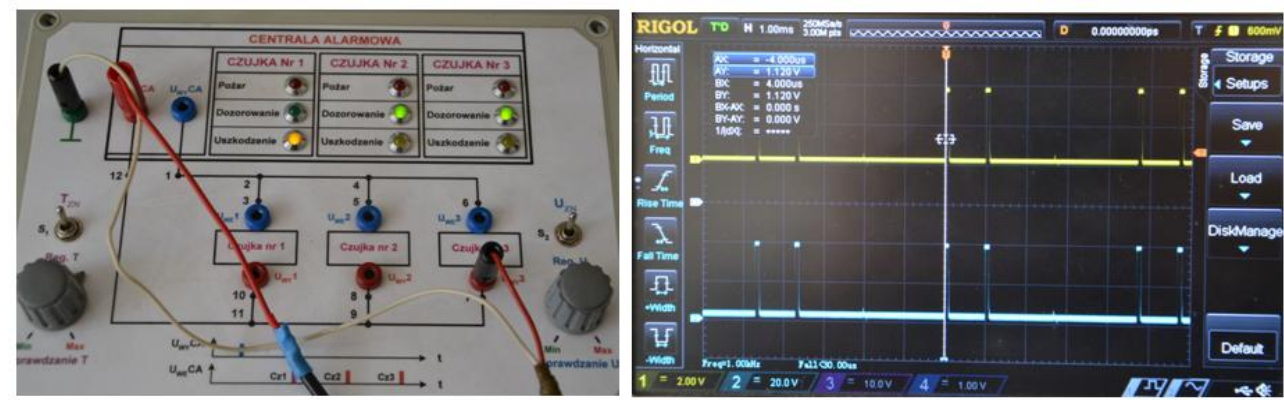

Rys. 11. Wtaczone uszkodzenie nr 3: widok wskazania CA i zobrazowanie na oscyloskopie - wynik procesu identyfikacji uszkodzenia
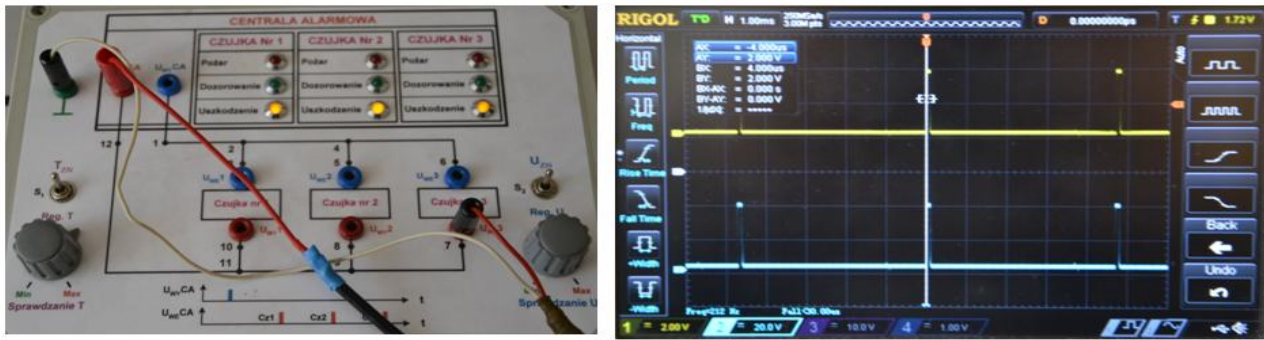

Rys. 12. Wtaczone uszkodzenie nr: widok wskazania CA i zobrazowanie na oscyloskopie - wynik procesu identyfikacji uszkodzenia

Tab. 5. Tabela diagnostyczna do realizacji sprawdzenia $n r x$.

\begin{tabular}{|c|c|c|}
\hline \multicolumn{2}{|r|}{ Zadane uszkodzenie } & Włączony wyłącznik $U_{\mathrm{y}}$ \\
\hline \multirow{4}{*}{ 豙 } & Objaw & $\begin{array}{l}\mathrm{O}_{1} \text {. Świecą żółte diody } \mathrm{w} \text { kanałach } \\
\text { czujek ... }\end{array}$ \\
\hline & Hipoteza & Brak impulsów na wyjściu CA czujek ... \\
\hline & Polecenie sprawdzenia & Sprawdzić $\mathrm{T}_{\mathrm{D}}$ i $\mathrm{T}_{\mathrm{G}} \mathrm{W}$ kanale czujki $\mathrm{nr} \ldots$ \\
\hline & $\begin{array}{l}\text { Wynik sprawdzenia } \\
\text { Objaw }\end{array}$ & $\begin{array}{l}\mathrm{O}_{2} . \text { Impuls czujki } 1 \text { znajduje się poza } \\
\text { „Bramką pomiarową” }\end{array}$ \\
\hline \multirow{3}{*}{ 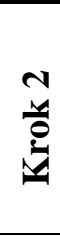 } & Hipoteza & $\begin{array}{l}\text { Uszkodzony układ pomiaru amplitudy } \\
\text { napięcia wyjściowego czujek w CA......... }\end{array}$ \\
\hline & Polecenie sprawdzenia & $\begin{array}{l}\text { Sprawdzić parametry impulsów na wejściu } \\
\text { CA czujek nr ..... i .. (czujki nr ..)... }\end{array}$ \\
\hline & Wynik sprawdzenia - Objaw & $\mathrm{O}_{3}, \ldots \ldots \ldots \ldots \ldots \ldots \ldots$ \\
\hline & $\begin{array}{l}\text { Impuls czujki } 1 \text { znajduje się poza } \\
\text { „Bramką pomiarową” - Uszkodzona CA. }\end{array}$ \\
\hline
\end{tabular}


Teaching methodology of the diagnosing process on the example of the fire...

Metodyka nauczania procesu diagnozowania na przykładzie systemu sygnalizacji...

Studenci realizują proces diagnozowania stanu technicznego i funkcjonalnego w systemie sygnalizacji pożarowej po zadaniu przez nauczyciela określonego uszkodzenia. Pomocne w tym działaniu są tabele diagnostyczne (patrz przykładowa tabela $\mathrm{nr} 5$ ), które studenci są zobowiązani uzupełnić określonymi zapisami $[1,2,4,6,11,16,17,19]$.

\section{Wnioski}

W artykule przedstawiono opracowane w Zakładzie Eksploatacji Systemów Elektronicznych WEL WAT stanowisko i ćwiczenie laboratoryjne dotyczące metodyki procesu nauczania diagnozowania systemu SSP. Wartości amplitudy impulsów, czasy ich trwania, położenie bramek pomiarowych, itd. odpowiadają rzeczywistej centrali alarmowej wykorzystywanej w realnych warunkach. Zadaniem studentów, podczas praktycznej realizacji ćwiczenia laboratoryjnego, jest postawienie w końcowym efekcie diagnozy odnośnie stanu systemu sygnalizacji pożaru. Wykorzystując schemat funkcjonalny SSP (rys. 3) studenci określają rodzaj i przyczynę uszkodzenia a ponadto utrwalają wiedzę w zakresie ogólnych zasad diagnozowania - a zwłaszcza wnioskowania diagnostycznego na podstawie zaobserwowanych objawów stanu diagnozowanego układu $[3,5,8,14,16,18,20,21]$. Ćwiczenie scharakteryzowane w powyższym opracowaniu stanowi jedno z kilku podobnych merytorycznie zadań laboratoryjnych, które wykonują studenci Wydziału Elektroniki WAT w ramach m. in. przedmiotu „Eksploatacja systemów bezpieczeństwa” oraz „Podstawy eksploatacji systemów”.

\section{Literatura}

[1] Będkowski L., Dąbrowski T.: Podstawy eksploatacji, cz. II, Podstawy niezawodności eksploatacyjnej. Warszawa: Wojskowa Akademia Techniczna, 2006.

[2] Dąbrowski T., Paś J., Olchowik W., Rosiński A., Wiśnios M.: Podstawy eksploatacji systemów, Laboratorium. WAT Warszawa 2014

[3] Burdzik R., Konieczny Ł., Figlus T.: Concept of on-board comfort vibration monitoring system for vehicles. J. Mikulski (Ed.): Activities of Transport Telematics, TST 2013, CCIS 395. Springer, Heidelberg 2013. pp. 418-425.

[4] Dyduch J., Paś J., Rosiński A.: Podstawy eksploatacji transportowych systemów elektronicznych. Wydawnictwo Politechniki Radomskiej, Radom 2011.

[5] Kołowrocki K., Soszyńska-Budny J.: Reliability and safety of complex technical systems and processes. Springer, London 2011

[6] Żółtowski B., Niziński S.: Modelowanie procesów eksploatacji maszyn, AT-R 2002

[7] Paś J., Dąbrowski T.: Metodyka nauczania diagnozowania systemów bezpieczeństwa na przykładzie systemów sygnalizacji włamania $i$ pożaru, Diagnostyka, PTDT, Nr 2(46)/ 2008, pp. 101-104. 
[8] Laskowski, D., Łubkowski, P., Pawlak, E., Stańczyk, P.: Anthropotechnical systems reliability. In: the monograph „Safety and Reliability: Methodology and Applications - Proceedings of the European Safety and Reliability Conference ESREL 2014", editors: Nowakowski T., Młyńczak M., JodejkoPietruczuk A. \&Werbińska-Wojciechowska S. CRC Press/Balkema, London, 2015, pp. 399-407.

[9] Paś J.: Eksploatacja elektronicznych systemów transportowych. Uniwersytet Technologiczno - Humanistyczny, Radom 2015.

[10] Rosiński A.: Modelowanie procesu eksploatacji systemów telematyki transportu. Oficyna Wydawnicza Politechniki Warszawskiej, Warszawa 2015.

[11] Siergiejczyk M., Paś J., Rosiński A.: Issue of reliability-exploitation evaluation of electronic transport systems used in the railway environment with consideration of electromagnetic interference. IET Intelligent Transport Systems 2016, doi: 10.1049/iet-its.2015.0183.

[12] Siergiejczyk M., Paś J., Rosiński A.: Train call recorder and electromagnetic interference. Diagnostyka 2015, vol. 16, no. 1, pp. 19-22.

[13] Siergiejczyk M., Rosiński A., Paś J.: Analysis of unintended electromagnetic fields generated by safety system control panels. Diagnostyka 2016, vol. 17, no. 3, pp. 35-40.

[14] Duer S., Zajkowski K., Duer R., Paś J.: Designing of an effective structure of system for the maintenance of a technical object with the using information from an artificial neural network, Neural Computing \& Applications. Vol. 23, No. 3-4, pp. 913-925, 2013.

[15] Zajkowski K., The method of solution of equations with coefficients that contain measurement errors, using artificial neural network, Neural Computing and Applications, Volume: 24, Issue: 2, pp. 431-439, 2014.

[16] Stawowy M., Dziula P.: Comparison of uncertainty multilayer models of impact of teleinformation devices reliability on information quality. In: "Proceedings of the European Safety and Reliability Conference ESREL 2015”, editors: L. Podofillini, B. Sudret, B. Stojadinovic, E. Zio, W. Kröger. CRC Press/Balkema, 2015. pp. 2685-2691.

[17] Duer S.: Expert knowledge base to support the maintenance of a radar system, Defence Science Journal, Vol. 60, No. 5, pp. 531-540, 2010.

[18] Sumila M.: Selected aspects of message transmission management in ITS systems. In: the monograph "Telematics in the transport environment", editors: Jerzy Mikulski, given as the monographic publishing series „Communications in Computer and Information Science”, Vol. 329. SpringerVerlag, Berlin Heidelberg 2012, pp. 141-147.

[19] Duer S., Duer R.: Diagnostic system with an artificial neural network which determines a diagnostic information for the servicing of a reparable technical object, Neural Computing \& Applications, Vol. 19, No. 5, pp. 755-766, 2010.

[20] Smyczek J., Zajkowski K: Simulation of overvoltages for switching off lagging load from mains. Conference: 2nd International Industrial Simulation Conference Location: Malaga, SPAIN Date: 2004, pp. 278-281, 2004. 
Teaching methodology of the diagnosing process on the example of the fire...

Metodyka nauczania procesu diagnozowania na przykładzie systemu sygnalizacji...

[21] Wiśnios M., Dąbrowski T., Bednarek M.: Metoda zwiększania poziomu bezpieczeństwa zapewnianego przez system biometrycznej kontroli dostępu. Przegląd Elektrotechniczny 2015, nr 10, s. 229-232.

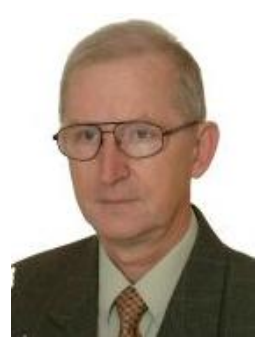

Dr hab. inz. Tadeusz Dabrowski, profesor nadzwyczajny na Wydziale Elektroniki Wojskowej Akademii Technicznej. Jego zainteresowania naukowe koncentruja się $w$ obszarze teorii eksploatacji - głównie na diagnostyce technicznej. Do ważniejszych zagadnień, którymi się zajmuje należą: diagnostyka obiektów technicznych $i$ systemów antropotechnicznych, optymalizacja procesów diagnostyczno-obshugowych, niezawodność eksploatacyjna obiektów (Udziat 30\%).

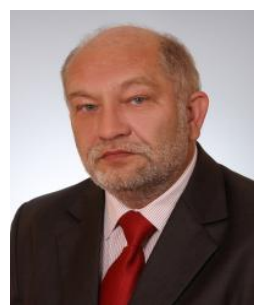

Dr hab. inz. Jacek Paś, profesor nadzwyczajny na Wydziale Elektroniki Wojskowej Akademii Technicznej. Jego zainteresowania naukowe obejmuja analize niezawodnościowoeksploatacyjna elektronicznych systemów bezpieczeństwa, systemów telematyki transportu oraz zagadnienia kompatybilności elektromagnetycznej. $W$ dorobku naukowym posiada kilkadziesiąt publikacji naukowych (Udziat 40\%).

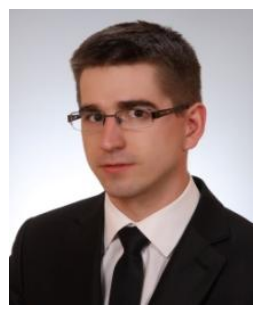

Dr inż. Michat Wiśnios, adiunkt na Wydziale Elektroniki Wojskowej Akademii Technicznej. Jego zainteresowania naukowe obejmuja elektroniczne systemy zabezpieczeń. Zajmuje się metodami wiarygodnego rozpoznawania osób na podstawie cech biometrycznych, aw szczególności identyfikacja na podstawie obrazu twarzy. $W$ dorobku naukowym posiada kilkadziesiąt publikacji naukowych (Udział 30\%). 